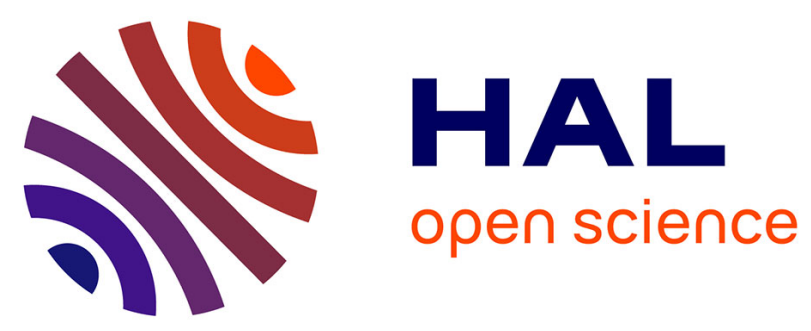

\title{
Stratigraphic Model of a Middle-Late Jurassic carbonate system (Mozduran Ridge, Kopet Dagh area, NE Iran)
}

Rooholah Noemani Rad, Damien Do Couto, Marie-Françoise Brunet, Luis Pomar, Franz T Fürsich, Seyed Ali Moallemi, Christian Gorini

\section{- To cite this version:}

Rooholah Noemani Rad, Damien Do Couto, Marie-Françoise Brunet, Luis Pomar, Franz T Fürsich, et al.. Stratigraphic Model of a Middle-Late Jurassic carbonate system (Mozduran Ridge, Kopet Dagh area, NE Iran). Marine and Petroleum Geology, 2021, 128, pp.104976. 10.1016/j.marpetgeo.2021.104976 . hal-03332165

\section{HAL Id: hal-03332165 \\ https://hal.science/hal-03332165}

Submitted on 2 Sep 2021

HAL is a multi-disciplinary open access archive for the deposit and dissemination of scientific research documents, whether they are published or not. The documents may come from teaching and research institutions in France or abroad, or from public or private research centers.
L'archive ouverte pluridisciplinaire HAL, est destinée au dépôt et à la diffusion de documents scientifiques de niveau recherche, publiés ou non, émanant des établissements d'enseignement et de recherche français ou étrangers, des laboratoires publics ou privés. 
Stratigraphic Model of a Middle-Late Jurassic carbonate system (Mozduran Ridge, Kopet Dagh area, NE Iran)

Rooholah NOEMANI RAD ${ }^{\mathrm{a}, \mathrm{b}^{*}}$, Damien DO COUTO ${ }^{\mathrm{a}}$, Marie-Françoise BRUNET $^{\mathrm{a}}$, Luis POMAR $^{\mathrm{c}}$, Franz T. FÜRSICH ${ }^{\mathrm{d}}$, Seyed Ali MOALLEMI ${ }^{\mathrm{b}}$, Christian GORINI ${ }^{\mathrm{a}}$

a Sorbonne Université, CNRS, Institut des Sciences de la Terre de Paris (ISTeP), 4 Place Jussieu, F-75005 Paris, France.

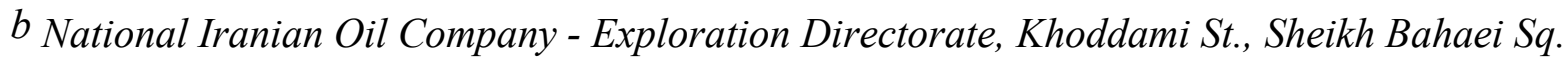
Post Code: 1994814695, Tehran, Iran

c Cátedra Guillem Colom, University of the Balearic Islands, Ctra. Valldemossa, Km 7.5, E07122 Palma de Mallorca, Spain

$d_{\text {GeoZentrum Nordbayern, Fachgruppe PaläoUmwelt, Friedrich-Alexander-Universität }}$ Erlangen-Nürnberg, Loewenichstr. 28, D-91054, Erlangen, Germany

*Corresponding author, e-mail address: $\underline{\text { r.noemani.rad@gmail.com }}$ 


\begin{abstract}
Lithostratigraphy and biostratigraphy of Middle to Upper Jurassic carbonate platforms of the Eastern Kopet Dagh (EKD), northeastern Iran were assessed. Up to $3000 \mathrm{~m}$ of sedimentological logs located along ten stratigraphic sections were investigated. At least five types of carbonate production systems were identified in the study area: (1) a mud-dominated platform carbonate topped by (2) an off-platform carbonate grain-production system, (3) a grain-reworking system deposited within basinal settings (gravity-driven reworking), (4) mounds built by tubular sponges and corals, and (5) prograding oolitic wedges. The first carbonate production system (Callovianearly Oxfordian) yields platy and solitary corals, together with stromatactis-like structures. The second carbonate production system is represented by upper Oxfordian off-platform grainstones. These two carbonate production systems comprise the Khaneh Zou Fm. The third system is characterised by oncoids, originating from the carbonate platforms. These oncoids, together with bioclasts, were transported into the Kimmeridgian hemipelagic succession of the Chaman Bid Fm. The last two carbonate production systems are common in the Mozduran Fm. Tithonian tubular sponges, corals mounds, and their related dismantling products constitute a major characteristic system of the Mozduran Fm. Shallowing-upward prograding clinoforms are a second characteristic system of the Mozduran Fm., whereby ooids, generated under shallow-water conditions, were shed downslope to form interbeds within basinal mudstones. Our findings suggest that the combination of $2^{\text {nd }}$ order eustatic sea-level changes with hydrodynamic processes as well as rift-inherited morphologies and climatic changes controlled the development and lateral facies evolution of the Middle to Upper Jurassic carbonate platforms. The description of these carbonate systems and of their morphology, together with stratigraphic interpretations may lead to exploration of complex structural-stratigraphic traps, thereby highlighting new potential hydrocarbon reservoirs in the EKD.
\end{abstract}

Keywords:

Middle-Upper Jurassic, platform/slope carbonate, carbonate production system, stratigraphic model, Kopet Dagh, Iran 
1 Introduction

In the Middle East and western Central Asian basins, Jurassic carbonate successions host some of the most important hydrocarbon reservoirs (e.g., Arabian platform in Alsharhan, 2014 and Amu Darya Basin in Ulmishek, 2004; Brunet et al., 2017). These have been described as shallow-water carbonate platforms forming during post-rift phase (e.g., Brunet et al., 2017; Sharland et al., 2001) with a variety of carbonate-production elements such as microbial mounds, oncoids/ooids, and bioclasts. The platform type is variable and depends on the geotectonic context and on chemical, physical, and biological processes that are dominantly controlled by variations in topography, climate, tectonic, ecological, and hydrodynamic conditions (e.g., Pomar and Kendall, 2008). During the Jurassic, climate and eustatic sea-level fluctuations (e.g., Haq, 2018; Sellwood and Valdes, 2008) exerted a major influence on carbonate platforms (e.g., Brigaud et al., 2008; Colombié et al., 2014; Korte and Hesselbo, 2011; Rogov and Zakharov, 2010).

This contribution focuses on the Middle to Upper Jurassic (MUJ) carbonate platform at the southern margin of the Turan Platform, Kopet Dagh. Nowadays forming a fold-and-thrust belt in northeastern Iran, the Kopet Dagh represents the results of successive extensional and compressional tectonic events related to the evolution of the Palaeotethys and Neotethys oceans and to the history of the central Iranian oceanic domains (e.g., Barrier et al., 2018; Berberian and King, 1981). The spectacular MUJ outcrops in the Eastern Kopet Dagh (as one of two regions of the Turan Platform where MUJ carbonates are exposed) provide a unique opportunity to investigate the facies and geometries of the carbonate platform-slope system and determine the effects of possible factors controlling their architecture. Several studies (e.g., Kavoosi et al., 2009; Lasemi, 1995; Robert et al., 2014; Zand-Moghadam et al., 2016) have shown that MUJ carbonates are characterised by distinct lateral facies and thickness variations. In this study, the Kardeh-Ardak area (hereafter called Kardeh area; Fig. 1B) has been chosen to better understand and characterise the sedimentological and structural pattern of the Middle to Upper Jurassic carbonate platform system. The Kardeh area offers spectacular outcrops where all stratigraphic units can be observed and contain a sufficient number of fossils to date. This paper reviews the stratigraphic framework of the region and provides a new depositional and stratigraphic framework for the eastern Kopet Dagh Basin (along the Mozduran Ridge). In addition, it presents a new geological map (Kardeh area) with detailed sedimentological logs and datings to better understand the different types of 
carbonate-production systems as well as the temporal and spatial sedimentary evolution of the MUJ carbonates across the study area. Finally, an attempt is made to investigate the possible synchronous deposition of the MUJ carbonates lining the margins of the Iran blocks and Turan platform, and the controlling factors and their impact on the sedimentary model.

\section{Geological setting}

The Kopet Dagh Basin, located in NE Iran, forms the southwestern margin of the Turan Platform (e.g., Lyberis et al., 1998; Robert et al., 2014) and is closely linked to the Amu Darya (Brunet et al., 2017; Ulmishek, 2004) and South Caspian basins (e.g., Brunet et al., 2010). The Main Kopet Dagh fault limits the Kopet Dagh Basin to the north (Fig. 1B). Towards the south, the Eastern Kopet Dagh (EKD) is limited by the Binalud Range, which lies along the Palaeotethys suture zone (PTSZ in Fig. 1A). Extending for more than $230 \mathrm{~km}$, the Mozduran Ridge connects the basement of the Kopet Dagh exposed at the Aghdarband erosional window to the highly faulted Hezar Masjed Mountains (for the location see Fig. 1B). The regional Radkan/Kardeh anticline, our study area, is located in the Hezar Masjed Mountains zone (Fig. 1B).

Following the closure of the Palaeotethys, the Triassic succession of the Aghdarband Group is unconformably sealed by syn-rift Middle Jurassic siliciclastics of the Kashafrud Fm. (Fig. 2; Taheri et al., 2009) which are characterised by a shallowing-upward trend (Taheri et al., 2009). Carbonate sedimentation was started by marls and argillaceous limestones of the Chaman Bid Fm. (Fig. 2), deposited on the slope and basin adjacent to a carbonate platform (Fig. 3; Majidifard, 2003). The Chaman Bid Fm. mostly consists of well-bedded marly mudstones with bioclastic beds, cherty limestones, and ochre-coloured hemipelagic carbonates (Huber and Najmabadi, 1971). The age of the Chaman Bid Fm. is still debated and ranges from late Bajocian to early Tithonian across the Kopet Dagh Basin (Majidifard, 2003; Majidifard et al., 2017; Seyed-Emami et al., 1999). The Chaman Bid Fm. pinches out towards the easternmost part of the basin (e.g., Shurijeh valley, Fig. 3), where there is a Callovian hiatus (Fig. 2; Afshar-Harb, 1979; Robert et al., 2014).

Locally, between the longitudes $59^{\circ} 15^{\prime} \mathrm{E}$ and $60^{\circ} 15^{\prime} \mathrm{E}$, the Khaneh Zou Fm. is sandwiched between the Chaman Bid facies (Fig. 3). The Chaman Bid facies underlying the Khaneh Zou Fm. is hereafter referred to as Chaman Bid-1 unit, that overlying the Khaneh Zou Fm. as Chaman Bid2 unit (Fig. 3). The Khaneh Zou Fm. is composed of light grey, coarse-grained, rhombohedral to saccharoidal dolomite and micritic limestone layers (Huber and Najmabadi, 1971) representing 
open-marine, barrier, lagoonal and intertidal depositional environments (Nadjafi et al., 1999). At the type locality in Ortakand (Fig. 1B), calciturbidites in the upper part of the formation were dated to Oxfordian-Kimmeridgian (Huber and Najmabadi, 1971), while Afshar-Harb (1994) considered the entire Khaneh Zou Fm. as being late Callovian in age (based on foraminifera records).

The Mozduran Fm. overlies the Chaman Bid Fm. across the EKD. Its age is subject to discussion, ranging from Oxfordian to Valanginian (Adabi and Ager, 1997; Bozorgi-Rad et al., 2007; Hadavi and Khodadadi, 2014; Hosseiniyoon et al., 2017; Kadivar et al., 2017; Schlagintweit et al., 2019). In the easternmost Kopet Dagh, where the Chaman Bid Fm. is absent (Afshar-Harb, 1983), the Mozduran Fm., mostly made of coastal to shelf siliciclastics and few metre-thick carbonates, unconformably overlies the Kashafrud Fm. (Aghaei et al., 2018; Mahboubi et al., 2010; ZandMoghadam et al., 2016). Towards the west, the Mozduran facies mostly consist of paralic successions and sabkha evaporites with siliciclastic influence, as well as oolitic packstones and grainstones (Fig. 3; Afshar-Harb, 1979), deposited under marginal marine conditions (Aghaei et al., 2018; Kavoosi et al., 2009). In the geological maps of the EKD (i.e., Afshar-Harb, 1983; Rowshanravan and Mafi, 2004), from the Ghorghoreh locality (Figs. 1B, 3) towards the east where the typical Chaman Bid Formation is absent, the Jurassic carbonates are known as the Mozduran Formation (sensu lato). However, from this locality westwards, the Middle and Upper Jurassic carbonates are subdivided into three formations: Chaman Bid, Khaneh Zou, and Mozduran (sensu stricto) (Figs. 2, 3).

In the EKD, different types of carbonate platforms have been described ranging from homoclinal ramp (Aghaei et al., 2018) to rimmed shelf (Kavoosi et al., 2009; Lasemi, 1995). Kavoosi et al. (2009) highlighted a sharp transition from shallow-marine to deep-water conditions. They considered that the Upper Jurassic carbonates first developed on a rimmed shelf platform and evolved into a ramp system during late Kimmeridgian. The observation of build-ups (reefal complexes) in subsurface data led Kavoosi et al. (2009) to conclude that the carbonates formed on a rimmed shelf. However, Aghaei et al. (2018) assumed a homoclinal ramp was present throughout the EKD during the Late Jurassic.

The beginning of the Early Cretaceous is marked by deposition of the Shurijeh Fm. It is characterised by siliciclastic red beds deposited in fluvial to shallow-marine environments (Fig. 3; Hosseinyar et al., 2019). Some authors (e.g., Aghaei et al., 2018; Kadivar et al., 2017) assumed 
the boundary between the Mozduran and Shurijeh formations to be a paraconformity, although the contact is transitional in some areas such as Kardeh area (Fig. 1B; Afshar-Harb, 1979; Huber and Najmabadi, 1971).

\section{Material and methods}

\subsection{Site investigations, sedimentological logging, and biostratigraphy}

In the Eastern Kopet Dagh, from east to west, a total of $3000 \mathrm{~m}$ of sedimentary successions along ten stratigraphic sections (more or less separated by $\sim 15 \mathrm{~km}$ ) were measured. The main surfaces, stratal geometries, and facies changes were marked on the observation map to localise the platform-to-basin facies transition in the Middle to Upper Jurassic carbonates. Microfacies analysis from previous studies (Aghaei et al., 2018; Kavoosi, 2010; Lasemi, 1995; Noemani Rad et al., 2017b; Zand-Moghadam et al., 2016) are combined with our field observations (F1 to F10 in Table 1). Lithofacies classification is based on texture, growth-fabric descriptors, surfaces, grain type (diagnostic and complementary), physical sedimentary structures and bioturbation, stratal pattern (morphology, thickness and lateral extension of beds), and depositional energy. Coral growth-fabric was described based on continuity, regularity and dominant growth forms, according to the classification of Insalaco (1998): platestone (platy to tabular colonies), sheetstone (sheetlike and lamellar colonies), domestone (domal and irregular colonies), pillarstone (branching colonies, rod and tubular solitary forms), and mixstone (not dominated by a single growth form but including a variety of growth forms). We used the term "boundstone" as a generic term for autochthonous limestones without specific mode of organic binding (Embry and Klovan, 1971).

More than 100 samples of ammonites, echinoids, and brachiopods were collected from the Khaneh Zou, Chaman Bid, and Mozduran formations at the Bazangan/Gas Pipeline, Abgarm, Ortakand, and mainly Kardeh localities (see Fig. 1B for location). They were dated and compiled with information from other publications (Fig. 3; Adabi and Ager, 1997; Ghasemi-Nejad et al., 2005; Hosseiniyoon et al., 2017; Kadivar et al., 2017; Madani, 1977; Majidifard et al., 2017; Sajjadi and Hadad Tavakol, 2008; Schlagintweit et al., 2019; Taheri et al., 2009) to constrain palaeoecological interpretations (Table 2). Preparation and dating of the ammonites were done by M. Majidifard (Geological Survey of Iran) and P. Courville (University of Rennes 1, France). The studied fossils are stored in the Exploration Directorate of the National Iranian Oil Company. 


\subsection{Geological mapping and satellite image analysis}

All the measured Reference Surfaces (RS10-70) and acquired Garmin GPS data (accurate to within 5-10 metres under normal conditions) were mapped and correlated on satellite images (Esri and Google Earth $^{\odot}$ ). Analysis of satellite images and calibration with the sedimentological logs (i.e., Fig. 4) provided useful information on the geometry of the strata and facies/thickness variation of the units. The satellite image interpretation should be treated with caution as it needs to be calibrated by field surveys. For this reason, the satellite image analysis along the Mozduran Ridge and Kardeh area was carried out between two field seasons to have a chance to approve/reject this interpretation. For the purpose of this study a 1:25k scale digital new geological map (Fig. 5) has been produced for the Kardeh area, based on our field surveys, 1:250k and 1:100k scale regional geological maps, satellite images, 1:25k scale topographic maps and an extensive compilation of published data (e.g., Afshar-Harb, 1979; Bozorgnia, 1972; Huber and Najmabadi, 1971; Kavoosi, 2010; Movahed, 1998; Narani et al., 1968). Supplementary data for the Kardeh area including the observation sites (A-L), reference surfaces (RS20-60), selected reference points in the sedimentary records, and location of field photos are presented on a Google Earth map in the appendix.

\section{Biostratigraphy}

\subsection{Late Bajocian-Bathonian}

The biostratigraphy of the Kashafrud Fm. is mostly studied with the help of ammonites. Garantiana and parkinsoni zones (A1 in Table 2) are attributing a late Bajocian age (Hosseiniyoon et al., 2017) to the lower erosional contact of the Kashafrud Fm. (RS10 in Fig. 4B). On the southern flank of the Kardeh anticline (site E, Figs. 5, 6A), a 5-m-thick shaly ammonite-sponge-rich carbonate interval occurs on the top of the formation. In the basal part of this interval, two ammonites of the genus Ebrayiceras (generally considered as the microconch subgenus of Morphoceras; Buckman, 1923) indicate an early Bathonian age (zigzag Zone, also observed by Majidifard, 2003). This age agrees with previous studies that pointed out a time interval of the Kashafrud Fm. from the late Bajocian (A1 in Table 2; Hosseiniyoon et al., 2017) close to its lower boundary (RS10 in Fig. 4B) to the late Bathonian (e.g., A3 in Table 2; Taheri et al., 2009) close to its upper boundary (RS20 in Fig. 4). 


\subsection{Callovian}

Callovian age ammonites were found in the Chaman Bid-1 unit (RS30 in Fig. 4) and the lower part of Khaneh Zou Fm. The ammonites Choffatia and Macrocephalites (A4 and A5 in Table 2) confirm an early Callovian age (Fig. 3) attributed to the Chaman Bid-1 unit. The lower part of the Khaneh Zou Fm. (below RS32 in Fig. 4) is relatively poor in index-fossils. Ammonites collected from the upper part of the 5-m-thick fossiliferous well-bedded limestones at the southern flank of the Kardeh anticline (Hecticoceras cf. lunuloides, Reineckeia anceps, Phylloceras sp., Calliphylloceras sp., and Sowerbyceras sp.) indicate a Callovian age (anceps Zone; A6 in Table 2; Majidifard, 2003; Seyed-Emami et al., 2013).

\subsection{Oxfordian}

The occurrence of Dichotomoceras sp. (A7 in Table 2) at the site J (Fig. 5) in the hemipelagic facies of the Chaman Bid-2 unit indicates a late Oxfordian age (bifurcatus Zone; Majidifard, 2003). Subdiscosphinctes sp. (late Oxfordian, bimammatum Zone), Euaspidoceras sp. (A8 in Table 2), Perisphinctidae, and Calliphylloceras sp. were also found at site G (Figs. 5, 6A-B) in the upper part of the Khaneh Zou Fm. (site G2 in Fig. 7A). Fossils extracted from layers between the calciturbidites (KhZ* in Fig. 6A-B) yielded the ammonite Euaspidoceras sp. indicating a late Callovian-late Kimmeridgian age (Majidifard, 2003; Parent et al., 2014). Therefore, an Oxfordian age is assigned to the upper part of the Khaneh Zou Fm. and the lower part of Chaman Bid-2 (marls/mudstones and cherty limestones). Indeed, the upper part of the Khaneh Zou Fm. and the slope carbonates of the Chaman Bid-2 are interfingering in the Oxfordian. This observation indicates that the contact between the Khaneh Zou Fm. and the Chaman Bid-2 (RS40 in Fig. 4B) is diachronous, although the Chaman Bid-2 unit is seemingly separated from the Khaneh Zou Fm. by a sharp break in sedimentation (onlap surface, RS40 in Fig. 6C).

Diceratid? bivalves, the earliest rudists (middle Oxfordian-early Valanginian), observed at the topmost part of the Khaneh Zou Fm., may be assigned a late middle Oxfordian-early Kimmeridgian age as documented by several studies in the northern Tethys (e.g., Sha et al., 2020; Skelton and Smith, 2000; Zheng et al., 2011). 


\subsection{Kimmeridgian}

The occurrence of Orthosphinctes sp. (platynota Zone; early Kimmeridgian; Hosseiniyoon et al., 2017) and Perisphinctidae sp. (A9 in Table 2) at site $J$ in the hemipelagic facies marks a Kimmeridgian age for the upper part of Chaman Bid-2 unit.

\subsection{Tithonian}

The ammonite Richterella richteri (A10 in Table 2) occurring towards the east (south of the Bazangan village, Fig. 1B) indicates an early Tithonian age (fallauxi Zone, richteri subzone) for the lower part of the Mozduran Fm. (Hosseiniyoon et al., 2017). This dating is in agreement with the age reported by Schlagintweit et al. (2019) for the Mozduran Fm. (Fish Farm locality, Fig. 1B). Their dating is based on the assemblage of some taxa of Dasycladales [Campbelliella striata (Carozzi), Montenegrella florifera Bernier, Petrascula bugesiaca Bernier, Petrascula cf. bursiformis (Étallon), Triploporella sp.], benthic foraminifera [Neokilianina rahonensis (Foury \& Vincent), Spiraloconulus suprajurassicus Schlagintweit], and sponges (Paronadella? sp., Neuropora lusitanica G. Termier \& H. Termier, Thalamopora sp.).

\section{Facies associations}

\subsection{Siliciclastics}

In the easternmost part of the study area (e.g., Shurijeh valley in Fig. 1B), quartzarenites, feldspathic litharenitic sandstones, siltstones, and claystones (F1-F2 in Table 1) occur in the Mozduran Fm. (sensu lato). The bioclast content is low. Ripple marks (wavy, bifurcated, and current), low-angle lamination, and large-scale trough and planar cross-bedding (herringbone; Fig. 8A) are the main sedimentary structures in the sandstones (F1b) (Kavoosi et al., 2009; ZandMoghadam et al., 2016). Westwards, evaporitic beds (Fig. 4B; Narani et al., 1968) are intercalated between siltstones, red bedded claystones, and thin layers of stromatolites (F2). Continuing to the west, (between the localities Mozduran and Ghorghoreh; Fig. 1B), red bedded claystones disappear in favor of dolomitised platform carbonates (with some dasycladalean algae, bryozoans, ooids, etc.) of the Mozduran Fm. (sensu lato).

At the top of the Mozduran Fm. (sensu stricto), fine-grained sandstones (F1b) are intercalated between the carbonates (e.g., in section B2 of Fig. 7A). The main sedimentary structures are ripple marks (Fig. 8B) and erosional surfaces at the base of the layers. The bioclastic content is low. 


\subsection{Platform build-ups}

Stromatactis and coral mud-mounds.- Occurring in the Khaneh Zou Fm., these platform facies (F8 in Table 1; Fig. 9D-G) rest conformably on the well-bedded mudstones/wackestones of the Chaman Bid-1 unit. They consist of serpulids, in-place platy and solitary corals, together with stromatactis-like and zebra-like features (Fig. 10A-E), typical of mud-dominated build-ups. The build-ups are approximately $30 \mathrm{~m}$ wide and $10 \mathrm{~m}$ high. Thrombolitic mudstones and stromatactislike structures, 0.5- to 2-m-thick, occur in the build-ups (Fig. 9E). The internal structure of the build-ups is highlighted by autochthonous colonial organisms mostly parallel (plate) and perpendicular (pillars) to the external surface (Fig. 10A-B). The coral platestone to mixstone (sensu Insalaco, 1998) are embedded in a mudstone matrix. The top of the platform facies is covered by bioclastic grainstones (Fig. 9A; F10 in Table 1). Locally, it exhibits large thick-shelled bivalves (including diceratids?) and gastropods (including nerineids) floating in a fine- or coarsegrained matrix (Fig. 10G-I) and probably living in patches on a soft substrate (Fürsich et al., 2003). Small cavities within corals are infilled geopetally by calcareous mud (Fig. 10F) or calcite.

Tubular sponge-coral mounds.- Occurring in the Mozduran Fm., the mounds (sites F and B2 in Fig. 7A) are up to $20 \mathrm{~m}$ thick with an apparent diametre of 5 to 6 metres. They are characterised by a massive core and well-bedded flanks consisting of coral debris (Fig. 10A). Within and between frame-building tubular sponges and coral bouquets (Fig. 10E) the predominant microfacies is wackestone (F9). At the top, packstones, often dolomitised, contain densely packed sponge-like organisms (F6) identified as Cladocoropsis and Crescentiella (a new name for “Tubiphytes" in Senowbari-Daryan et al., 2008; Kavoosi et al., 2009; Noemani Rad et al., 2017b). At the Abgarm locality, the tubular sponges with wackestone matrix are overlain by stromatolite (Fig. 10B) and are mostly silicified.

\subsection{Laterally discontinuous deposits of the platform-top}

A southward lateral accreting wedge of bioclastic grainstones (F10 in Table 1) on top of the Khaneh Zou Fm. (Fig. 9A) was interpreted by Lasemi (1995) to have formed by sediment shed off the platform. The well-bedded grainstone clinoforms, inclined up to $20^{\circ}$, contain undifferentiated bioclasts, including echinoids, fragments of bivalves, and foraminifers with local occurrences of coral-bearing mounds (Fig. 9A). The bioclastic grainstones reach a thickness of $300 \mathrm{~m}$ at the platform margin. Foreset beds are of restricted height (less than $5 \mathrm{~m}$ ) and extend for a relatively 
short distance $(\sim 100 \mathrm{~m})$ with no argillaceous intercalations at either base or top. Satellite images reveal that these grainstones tend to thin and progressively disappear towards the southeast and the northwest (see green lines at the southern flank of the Kardeh anticline in Fig. 5).

In the topmost part of the Mozduran Fm. (Mozduran Ridge, between RS50 and RS55/60 in Fig. 4B), 20- to 70-m-thick shallowing-upward prograding clinoforms develop mostly towards the platform margin (northwestwards) and occasionally alongshore (i.e., northeastwards at the Mozduran locality). They mostly consist of oolitic grainstones, which were generated in shallowwaters, and downlap onto finer-grained offshore sediments.

\subsection{Upper slope deposits}

Occurring in the Khaneh Zou Fm., upper slope deposits (flank facies) consist of dm-thick graded floatstone/rudstone (F7 in Table 1) and grainstone beds with mud clasts (F4; Fig. 11). The dominant grains are poorly sorted and rounded. The beds, encased in the muddy facies, contain reworked oncoids, corals, Trichites, and molluscs with variable size. They occur around and abutting on the build-ups. The floatstones/rudstones are interpreted as gravity deposits derived from the platform facies (F8). Probably, the grainstones are derived from the bioclastic grainstones deposited on top of the platform facies (F10; red polygon in Fig. 11).

Occurring in the Mozduran Fm., upper slope deposits consist of 8- to 10-m-thick rudstone and floatstone beds (site B2 in Fig. 7A), containing sponges and coral fragments. They are interbedded within mudstones-wackestones with bioclasts and ostracods. Locally, exotic blocks of wackestone (F9 in Table 1; Fig. 12C) are encased in rudstone beds. The exotic blocks are several metres in diametre and contain large tilted coral bouquets (Fig. 12D). They are gravity deposits transported for short distances on the upper slope. The Mozduran Fm. (site B in Fig. 7A) is mostly composed of alternations of mudstones and floatstones-rudstones with a general shallowing-upward trend.

\subsection{Lower slope and basinal carbonates}

Autochthonous carbonate sediments.- These sediments consist of cherty wackestones/packstones (arrowed in Fig. 13B; F5 in Table 1) and monotonous marl/mudstones (F3, Fig. 14A-B) with sponges, oysters, ammonites, and some irregular endogenic burrow networks reminiscent of Megagrapton (Fig. 13E), a trace fossil generally related to deep-sea environments (Seilacher, 1977). 
Calciturbidites and mass transport deposits (MTDs).-Calciturbidites (F4 in Table 1; Fig. 13A-D) reach $\mathrm{ca}$. $100 \mathrm{~m}$ of thickness (KhZ* in Fig. 6B). They consist of 5- to 10-m-thick graded grainstone beds truncating cherty wackestones, and exhibit ripple marks with finer materials at the top (Table 1; Fig. 13B). They can be followed laterally over a distance of up to $500 \mathrm{~m}$. Apparently, calciturbidites and slumps represent a lateral (down-dip) equivalent of the platform facies of the Khaneh Zou Fm. However, the junction between the main carbonate succession (KhZ in Fig. 6A at site E) and the calciturbidites (KhZ* in Fig. 6A at site D) is eroded in the Kardeh area. The base of the Khaneh Zou Fm. is marked by an erosional surface (black arrow in Fig. 6B) forming a northtrending gully-like feature, the down-stream area of which fed with gravity deposits. Up-section in the Chaman Bid-2 unit (site B in the Kardeh area and at Abgarm), other turbiditic rudstone packages (Fig. 14C) intercalated within hemipelagic limestones with reworked oncoids, corals, and brachiopods (Fig. 14E-F) are up to $2 \mathrm{~m}$ thick and have a lateral extension of more than $15 \mathrm{~m}$. Size of the clasts is decreasing upwards. In addition, several m-thick intercalations of Lithocodiumpackstones (F6) with reworked bivalves (e.g., Trichites) occur in the Chaman Bid-2 unit. These turbiditic beds probably record transport of platform material to deeper parts of the basin.

At many horizons below the turbiditic bodies of the Khaneh Zou Fm., contorted cherty wackestones (F5 in Table 1) document destabilization and slumping (Fig. 13A). At Ortakand (Fig. 1B), a 5-m-thick chert-bearing MTD, consisting of micro-conglomerate with echinoids and unidentified bioclasts, truncates the underlying layers. The thick MTD interval and slumps at this locality occur far from the platform carbonates. At the Gas Pipeline locality (Fig. 1B) the chertrich mudstones (F3) are covered by a $\sim 3$-m-thick conglomeratic debris flow.

Olistoliths, embedded in the hemipelagic deposits of the Chaman Bid-2 unit, are several metres in diametre. They are composed of black mudstone (F3 in Table 1; Fig. 14D). The emplacement of the olistoliths in the soft hemipelagic facies generated local folds of short wave length.

\section{Depositional systems across the EKD}

A stratigraphic and depositional model of the Eastern Kopet Dagh (EKD) for the Middle to Upper Jurassic succession was synthesised in the form of an interpretative sketch based on the field observations, satellite images, biostratigraphic data, and reports of previous studies performed in or in the vicinity of the study area (Fig. 15). The stratigraphic sections are positioned from proximal (Shurijeh valley) to distal (Ortakand and Hammam Qaleh) in Figure 15. This scheme aims at 
placing the Kardeh area in a more regional context. Historical names of the formations observed in the field and the reference surfaces (RS10-60) were included in the general framework. Six depositional systems characterised by different lithofacies have been defined for the Callovian to Tithonian time interval (Fig. 15). Microfacies analyses of previous studies (Aghaei et al., 2018; Kavoosi, 2010; Lasemi, 1995; Noemani Rad et al., 2017b) are used to interpret depositional systems in this study.

\subsection{Fluvio-estuarine/deltaic system}

This system is composed of sandstones with a few shales and paralic deposits (F1-2 in Table 1). Wave-rippled, well-sorted, and large-scale planar and trough cross-bedded sandstones (F1b) in the easternmost part of the study area (e.g., Shurijeh valley in Figs. 4B, 15) indicate a high-energy coastal environment. The presence of herringbone cross-bedding (Fig. 8A) may indicate the influence of tidal currents . According to Zand-Moghadam et al. (2016) the alternations of sandstones with siltstones and red bedded, only little-bioturbated claystones denote a tidal flat environment. The fine-grained sandstones with ripple marks and erosional base, deposited at the top of the Mozduran Fm. (sensu stricto), are interpreted to document the influence of siliciclastic influx from the hinterland.

\subsection{Inner-platform system}

This system is composed of mud-dominated low-energy carbonates and marls. The lithofacies include oncolitic packstone with bioclasts, wackestone with ostracods, sponges and coral bouquets (F6 and F9 in Table 1). At the eastern side of the Mozduran Ridge (Fig. 15), this system comprises lagoonal and tidal flat deposits involving lime mudstones, dolo-mudstones and gypsum/anhydrite nodules/layers towards the southeast (Kavoosi et al., 2009). Ostracod wackestones, containing calcite pseudomorphs, with birds-eye fabric (e.g., at the locality Fish Farm; Fig. 1B) in the Mozduran Fm. indicate restricted connections of the platform with open-marine waters (Kavoosi

et al., 2009, and references therein). Dasycladales in packstones, reported and dated by Schlagintweit et al. (2019) at the Fish Farm locality, are common within this system, which constrain the bathymetry to the euphotic zone (Pomar et al., 2012). 


\subsection{Mid-platform system}

Main features, observed in the Kardeh area and at Ghorghoreh (Fig. 15), are low-energy carbonate mud and carbonate build-ups (during the Callovian), including floatstone/rudstone and platestone to mixstone growth-fabrics (F7 and F8 in Table 1). Along the Mozduran Ridge, oolitic grainstones (between RS50 and RS55/60 in Fig. 4B) are considered to have been deposited in the euphotic zone on an inner to mid platform during the Tithonian. This interpretation is supported by the occurrence of tempestites (Kavoosi et al., 2009) and ooids, the latter requiring light for their growth (Pomar, 2020). Ooids in prograding wedges can move a long distance obliquely (down-dip and alongshore from inner- to mid-ramp) until they reach the edge, from where they avalanche downslope and prograde onto basinal mudstones (Pomar, 2020) (F3 in Table 1).

\subsection{Platform margin system}

This system is characterised by bioclastic grainstones, accumulated by off-platform shedding (F10 in Table 1). It caps the platform facies (Fig. 9A; red polygon in Fig. 11). Diagenetic processes such as dolomitisation occur in this depositional system (Fig. 9C). The bioclasts consist of echinoids, thick-shelled bivalves, and foraminifera (Table 1). Off-platform shedding sediments (grainstone) was directed towards the southwest, whereas gravity flow sediments (calciturbidites) were directed towards the northwest.

\subsection{Upper slope system}

This system includes mud-dominated build-ups, floatstones/rudstones (F8 and F7 in Table 1), oncolitic packstones, and calciturbidites (F4 and F6 in Table 1). The oncolitic packstones and calciturbidites were deposited on the upper slope and extended down to the basin. The depositional system of mud-dominated build-ups is interpreted as part of the mid platform to upper slope. The absence of light-dependent organisms in the mud-dominated build-ups suggests that the build-ups developed below the wave base in the meso- to oligophotic zone (Pomar, 2020). This interpretation is also supported by the fabrics of the autochthonous colonial organisms with mudstone matrix. None of the biogenic components of the mud-dominated build-ups (platy corals, serpulids, and stromatactis-like structures) occurs in the shallow-water inner-platform. Jurassic platy corals were common in relatively deep-water environments (but still required some light; Gill et al., 2004; Insalaco, 1996). Serpulids do not require light, and microbial coatings can grow in very poorly 
illuminated environments (e.g., Leinfelder et al., 1994; Pomar, 2020). Light-dependence of coated grains and oncoids cannot fully be rejected but, if any, low-light conditions (oligophotic zone) would have been sufficient (Al-Awwad and Pomar, 2015). The thrombolitic mudstones and stromatactis-like structures with the lack of calcareous algae most likely formed below the wave base and photic zone (e.g., Flügel, 2010). On the upper slope, biogenic components of shallowwater origin (Trichites and molluscs) are very rare and might have originated from grainstone shedding (F10), most likely having been transported downslope by turbidity currents.

\subsection{Lower slope to basinal system}

In the Kardeh area (Figs. 14, 15), this system comprises marl/mudstone, distal parts of calciturbidites, and cherty limestone (wackestone-packstone) with olistoliths (F3, F4, and F5 in Table 1). The lack of sedimentary structures, the intense bioturbation, and the monotonous hemipelagites, occasionally associated with cherts, slumps, and mass transport deposits with erosional base suggest a distal slope to basinal depositional environment.

\section{Sedimentary evolution}

The late Bajocian-Bathonian siliciclastics of the Kashafrud Fm. (Fig. 16A), the substratum of the carbonate system, are characterised by a shallowing-upward trend from the lower offshore to a shoreface setting (Fig. 7A). It is thinning over rift-inherited palaeo-highs or the shoulder of faulted blocks (Noemani Rad et al., 2017a). The early Callovian Chaman Bid-1 unit (Fig. 16B) onlaps onto the Kashafrud Fm. (RS30 in Fig. 4A). The thickness decreases from $\sim 90 \mathrm{~m}$ at the northern flank of the Kardeh anticline to less than $5 \mathrm{~m}$ at the southern flank (site E), with the stratum pinching out towards the south-southeast. From Callovian to Tithonian (-early Berriasian) at least five types of carbonate production systems were identified in the Eastern Kopet Dagh. The first carbonate factory, Callovian-early Oxfordian in age, corresponds to the mud-dominated build-ups containing platy corals, stromatactis-like structures, and serpulids in the Khaneh Zou Fm. (Fig. 16C). The results are high-relief, early cemented carbonate mounds that exported little carbonate material. For example, in the Kardeh area, geometrical analysis demonstrated a $25^{\circ}$ angle of the platform slope (measured by onlapping pattern of the Chaman Bid-2 unit onto the Khaneh Zou Fm.; see black arrows in Fig. 5). The Callovian carbonate platforms did not export much material to the basin, except perhaps some rare olistoliths (e.g., Fig. 14D) interbedded between autochthonous hemipelagic deposits (mudstones-wackestones with cherts). The platy corals, and 
stromatactis-like structures in mud-dominated build-ups suggest they developed at poorly illuminated depths, below the wave base (Pomar, 2020). The lack of siliciclastics indicates that the carbonate platform was largely or totally shielded from terrigenous influx during this period.

The second carbonate production system is the upper Oxfordian grainstones (Fig. 16D), shedding towards the south, along the former Callovian-lower Oxfordian platform margins. These bioclastic grainstones have commonly been interpreted as the product of currents impinging on shallow structural highs. This interpretation is supported here by the occurrence of bivalves (including diceratids?). Thick-shelled bivalves lived as sediment recliners in loosely packed clusters and low biostromes preferably in back-margin settings (Fürsich et al., 2003; Kauffman and Sohl, 1979). The low fragmentation of reworked shells (Figs. 9B, 10H-I) indicates that the bivalves were preserved close to the zone where they were living (only limited transport) and might have been reworked by episodic currents from a protected area to the platform margin. Parts of the upper Oxfordian grainstones were probably transported to the north as calciturbidites through upslope gullies (Fig. 16D). Basinward transport was found to be of limited extent, although the real dimension remains unknown (being beyond the scale of our field observations). The predominant limestone lithology indicates that the carbonate factory was shielded from terrigenous influx or that terrigenous influx was minor.

The third type of carbonate factory, Kimmeridgian in age, is related to the Chaman Bid-2 unit, where both hemipelagic facies and gravity deposits were observed. The predominant carbonate production in the basin, at the toe of the slope, was autochthonous hemipelagic carbonates with an influx of terrigenous clays resulting in shaly carbonates and marl (Fig. 16E). The proportion of gravity deposits within the Kimmeridgian hemipelagic facies (Fig. 14) is less than 10\% and increases up to $\sim 20 \%$ towards the east (e.g., at Abgarm). The coeval carbonate factory was far away towards the east. Redistribution of oncoids and bioclasts is inferred to have taken place from the wave-agitated zone to a more basinal setting. The occurrence of clay evidences that the basin was no longer protected from terrigenous influx or that terrigenous influx was stronger during Kimmeridgian time.

The fourth type of carbonate production system (Fig. 16F) corresponds to tubular sponge and coral mounds associated with debris products (Fig. 12A-B). Apparently, these were distributed in the study area during the Kimmeridgian-Tithonian time interval at the localities Ghorghoreh and 
Bazangan and during the Tithonian at the localities Abgarm, Fish Farm, and Kardeh. As in the Kimmeridgian time interval, the shaly limestone and marl lithology show that the platform was no longer protected from terrigenous influx or that terrigenous influx was stronger during Tithonian time.

The fifth type of carbonate production system, Tithonian (-early Berriasian) in age, corresponds to well-sorted oolitic packstones and grainstones. They occur as prograding clinoforms where the ooids, generated in shallow-waters, were shed downslope. They are distributed along the Mozduran Ridge, in the top of the Mozduran Fm. (between RS50 and RS55/60 in Fig. 4B). The production system exhibits most of the characteristics (lithofacies and geometry) of an infralittoral prograding wedge (Hernández-Molina et al., 2000; Pomar et al., 2015) that resulted from grain production in the wave-agitated zone.

\section{Discussion}

\subsection{Carbonate platform type}

As illustrated in the synthetic depositional model of the Eastern Kopet Dagh (Fig. 15), in the proximal part of the platform system (Shurijeh valley; Fig. 1B), the Callovian carbonates are replaced by a hiatus (Afshar-Harb, 1979). The lower siliciclastics (unit 1 in Fig. 15) of the Upper Jurassic Mozduran Fm. (sensu lato) change basinwards (northwestwards) to the prograding platform carbonates (the Khaneh Zou and Mozduran formations) and then to the hemipelagic facies of the Chaman Bid-2 unit. Towards the basin, the Middle-Upper Jurassic carbonates can be divided into two sequences (Fig. 15). The first sequence consists of the Chaman Bid-1 unit and the Khaneh Zou Fm., spanning the Callovian and early Oxfordian (5 and 4 in Fig. 15). The second sequence involves the Chaman Bid-2 unit and the Mozduran Fm. (3 and 2 in Fig. 15) and is late Oxfordian to Tithonian in age. If focusing on the Callovian-Oxfordian sequence along the Mozduran Ridge, the platform developed in a west-northwest direction (basinwards) on top of the siliciclastics of the Kashafrud Fm. with a slope angle of around $2^{\circ}$ (Fig. 15). This slope value is estimated by the sedimentological logs (Fig. 4B) along the Mozduran Ridge. It is an apparent dip, as the real dip direction cannot be inferred from a single 2D section, thus real dip should be equal or higher than $2^{\circ}$. At the Ghorghoreh locality, the inclination of the foreset beds of upper Oxfordian clinoforms is estimated to be about $15^{\circ}$ (apparent dip) based on the satellite images (e.g., Figs. 4A, 11) and the digital elevation map. During the late Oxfordian-Kimmeridgian (3 in Fig. 15) the 
inherited Callovian-Oxfordian morphology was onlapped by the Chaman Bid-2 unit (recording deepening-upward). Towards the southeast, the decrease of oncoid contents might indicate the back-stepping of the mid- and inner-platform facies (sensu Védrine et al., 2007). Subsequently, carbonates of the Mozduran Fm. (2 in Fig. 15) such as infralittoral prograding wedges developed over a ramp or distally steepened ramp towards northwest (basinwards).

In the Kardeh area, on the southern flank of the Kardeh anticline (site E in Fig. 5), the 5-m-thick ammonite-rich layers represent early Bathonian and Callovian biozones. The relatively large time span and the small thickness of the layers suggest that they are condensed. The 600-m-thick Callovian-lower Oxfordian carbonate succession (platy coral-stromatactis facies; Khaneh Zou Fm.) rests on top of the condensed sections, and pinches out towards the northwest (Fig. 5). Mapping the onlap of the Chaman Bid-2 unit onto the Khaneh Zou Fm. at the southern flank of the Kardeh anticline (site $\mathrm{C}$ in Fig. 5), a carbonate platform escarpment facing the northeast was inferred with a dip angle of $c a$. $25^{\circ}$. The capping grainstone interval disappears towards the southeast and northwest (see green lines at the southern flank of the Kardeh anticline in Fig. 5). The northwestern pinch-out is spatially consistent with the onlapping patterns terminating towards north. These boundaries probably mark the platform margin in a NW-SE direction. The thickness of the carbonate succession on the southern flank of the anticline decreases eastwards near the Kardeh dam (Fig. 5), making it possible to recognise a wedge-shaped geometry of the carbonate platform. As mapped in Fig. 5, the lateral development of the Kardeh platform was relatively limited.

By comparing the deposits on the southern and northern flanks of the Kardeh anticline, a SW-NE directed change from massive platform facies to slope-basinal facies was observed above the Chaman Bid-1 unit. Along the northern flank, slope carbonate deposits consist of slumped cherty limestones, calciturbidites and olistoliths embedded in mudstones, which imply the occurrence of gravity instability along the slope. The above-mentioned observations suggest the occurrence of a steep slope facing towards the northeast between the two flanks of the Kardeh anticline. In the Kardeh area, the NE-SW directed change from basinal facies to platform facies exhibits the characteristics of an isolated carbonate platform ( $c f$. Burgess et al., 2013), such as sharp-localised thickening, onlap of overburden or off-platform grainstones, and high-angle slope margins. However, due to the activities of the faults in the south-eastern plunge of the Kardeh anticline (near 
the Kardeh dam; Fig. 5), it has not been possible to assess the isolation of the Kardeh platform in that direction. Therefore, in a more regional context (Fig. 15), the Khaneh Zou carbonate platform in the Kardeh area is interpreted either as a spur of the regional platform or as an isolated carbonate platform. The possible slope (isolated carbonate platform scenario) or attachment to the main platform would be towards the southeast. The Khaneh Zou Fm. is spatially distributed across the highly faulted Hezar Masjed Mountains zone (Fig. 1B). This zone can be subdivided into dominotype blocks bounded by several faults. Some of these faults have been active during the Middle Jurassic rifting and affected the basement as seen from the seismic data (Noemani Rad et al., 2017a). During the late syn-rift and ensuing early post-rift setting, when the faulted blocks were highly rotated, differential subsidence of the blocks might have created nucleation sites or restricted carbonate production to narrow isolated areas, which may explain the limited areal distribution of the Khaneh Zou Fm.

\subsection{Factors controlling sedimentation}

\subsubsection{Hydrodynamic processes}

Environmental parameters such as regional hydrodynamic setting, nutrient availability, salinity, and temperature have broad effects on carbonate production systems (Pomar and Kendall, 2008). High-energy events such as storms, turbidity currents, and internal waves can control sediment redistribution across platforms and within basins at different bathymetric ranges (Pomar et al., 2012). Among high-energy events, storms and turbidity currents are most frequently documented, although internal wave deposits are increasingly recognised (Al-Awwad and Pomar, 2015; Pomar et al., 2012, 2019). Difficulties in recognizing deposits of internal waves arise from their potential interpretation as turbidites on slopes and basins, and as tempestites in shallower settings. For instance, in the sedimentary record of the Chaman Bid-2 unit at Abgarm and Kardeh localities (Fig. 14C, E, F), thin-bedded oncolitic and bioclastic sediments derived from the platform are interpreted as a result of turbiditic flows (calciturbidites) shed towards the basin. However, Pomar et al. (2014) provided another interpretation for this kind of deposits on a similar carbonate platform, i.e. episodic high-energy events induced by breaking internal waves may cause the same sedimentary products (Al-Awwad and Pomar, 2015; Alnazghah et al., 2013; Pomar, 2020). The authors suggested that internal waves would be impinging on the build-ups. As a result, clasts can be stirred up, moved off the build-ups, and deposited as short-transport gravity deposits in the 
basin (interbedded between deeper-water sediments). As the bulk density of bioclasts is generally low (Pomar et al., 2012), the turbulence and current velocity 'induced by internal waves' are sufficient to shed them off the build-up. As we do not have enough observations to conclude which high-energy event (turbidity currents, storms or internal waves) played a major role in the sedimentation of the thin-bedded oncolitic and bioclastic deposits in the outer-platform to basinal setting, the possibility of internal waves cannot be ruled out. Pomar (2020) discussed that the only prerequisite for internal waves is the stratification of two water masses with different density. It is possible to create this either by evaporation (salinity), temperature, or by freshwater addition from river outflow. In the study area, a connection to the open ocean might have existed during the Callovian-Kimmeridgian time interval (Barrier et al., 2018), connecting the Kopet Dagh and South Caspian basins to the Neotethys Ocean westwards where water stratification, background currents and tidal flows from the ocean may have interacted with sills. This hydrodynamic setting is beneficial for suspension-feeders (e.g., mostly bacteria for sponges, phytoplankton for bivalves, and zooplankton for corals) and this would explain why the build-ups of the Khaneh Zou Fm. occurred in a mid-platform to upper slope setting. This hypothesis can also explain why high amounts of debris flow (up to $20 \%$ of the Chaman Bid-2 unit) were observed in the lower slope to the basinal setting where the slope angle has been measured to be $\sim 2^{\circ}$.

In the literature, the occurrence of thin-bedded oncolitic and bioclastic beds in a basin close to a carbonate platform is generally interpreted as export of calcareous material during sea-level highstand (Schlager et al., 1994). The so-called "highstand shedding" (i.e., "a depositional system sheds most sediment into the adjacent basin during highstands of sea level" sensu Schlager et al., 1994) also explains the occurrence of calciturbidites (Lasemi, 1995). However, this concept contains some pitfalls due to some conceptual biases, which are explained by Pomar (2020): Schlager et al. (1994) studied several areas (e.g., the Bahamas, the Nicaragua Rise in the Caribbean, the Maldives archipelago in the Indian Ocean, and the Queensland Shelf) and concluded that during the Pleistocene sea-level highstand, much sediment was shed from the rimmed carbonate platforms and deposited in the adjacent basins. They mentioned that the recognition of the highstand shedding in pre-Pleistocene platforms is more difficult due to limitations in stratigraphic resolution. They did not discuss the possibility of tectonic factors, which could have also controlled the shedding of sediments in most of their studied carbonate platforms (e.g., the Bahamas) during the Pleistocene highstand. These authors defined the 
"highstand shedding" model based on the "modern" Caribbean-type reefal platforms, which did not exist before the Late Miocene (Pomar, 2020, and references therein). In the distally steepened ramp model, the shedding of sediment is controlled by the increased hydraulic energy on the seafloor resulting from sea-level fall (Pomar, 2020) and is not related to highstands of the sea-level. Shedding of sediment obligatorily needs two prerequisites: (1) a source of loose sediments and (2) the adequate water energy. Hence, a sea-level highstand is not the unique condition favouring shedding of sediment and such a process may as well be triggered during transgression (sea-level rise and erosion of platforms by waves), sea-level fall, or even during a lowstand (Pomar, 2020), keeping in mind that one cannot discard the likelihood of tectonics as a controlling factor.

\subsubsection{Latitudinal plate shift and climate change}

Several authors (Kent and Irving, 2010; Mattei et al., 2014; Muttoni et al., 2013, 2009; Muttoni and Kent, 2019; Torsvik et al., 2012) discussed that many of the climate patterns observed in the Jurassic sedimentary records can be explained by rapid plate movements. Mattei et al. (2014) showed that the stratigraphic succession of climate-sensitive facies changed as the Iranian domain passed twice from one climate belt to another one; (1) during the Mid-Late Triassic and Early Jurassic (from arid low latitudes to humid mid-high latitudes) and (2) during the Late Jurassic (from humid to arid). Recently, Muttoni and Kent (2019) proposed that Iran drifted southwards by $\sim 30^{\circ}$ from the humid temperate belt to arid tropical latitudes during the Oxfordian and Tithonian time interval (from $160 \mathrm{Ma}$ to $148 \mathrm{Ma}$; Fig. 17), the previous period from the Pliensbachian to Callovian (190-160 Ma) being a stillstand period at humid latitudes. With this new proposition, it is difficult to relate the change from a siliciclastic sedimentation regime (the Kashafrud Fm.) to the Callovian coral-dominated and frame-building biota of the Khaneh Zou Fm. to a change of latitudinal-controlled climatic belts. Besides a local structural control, the occurrence of gravity flows (calciturbidites and mass-transport deposits) can also be related to a worldwide climatic event such as a cooling event (e.g., Dromart et al., 2003; Ramajo and Aurell, 2008) that occurred during the Callovian-Oxfordian transition. Nevertheless, the occurrence of oncoids in the hemipelagic Kimmeridgian sediments suggests a prevailing arid and warm climate during this period, which is consistent with the conclusions of Muttoni and Kent (2019). Indeed, humidity changes in the hinterland have a negative impact on oncoid formation, which require relatively low sedimentation rates (Védrine et al., 2007). Thus, as indicated by previous authors for Iran (Mattei et al., 2014) and other Tethyan areas (Bartolini et al., 2003; Brigaud et al., 2008; Carpentier 
et al., 2006; Olivier et al., 2015; Pittet et al., 2000), the area was probably dominated by an arid and warm climate $\left(>25^{\circ} \mathrm{C}\right)$ during the Kimmeridgian (post-bimammatum Zone) to Tithonian time interval. This interpretation is also supported by deposition of evaporites on the inner platform, observed in the eastern part of the Mozduran Ridge (Figs. 3, 4).

\subsubsection{Differential subsidence and eustatic fluctuations}

In half-graben/tilted block systems, the impact of eustatic fluctuations on accommodation changes is overprinted by normal fault displacement and tectonic subsidence (Ravnås and Steel, 1998). However, in the late stage of rifting and during the post-rift regime, eustatic sea-level changes can be the most important factor controlling platform stratigraphy and geometry (Cross and Bosence, 2008).

In the Kopet Dagh Basin, an extensional event (rifting) occurred in the late Bajocian (Taheri et al., 2009). In the Eastern Kopet Dagh (EKD), Shahidi (2008) and Brunet et al. (2010) argued that the extensional phase passed to a thermal subsidence phase at the end of the Callovian (depending on the accuracy of the dating of the carbonates). This subsidence regime is characterised by a regional long wave-length trend between the margin and the centre of the basin encompassing all the EKD area (Fig. 15), despite local variations above rift-inherited blocks as interpreted in the Kardeh area. Two $2^{\text {nd }}$ order cycles of sea-level rise and fall occurred from the Bathonian to early Oxfordian, and from the middle Oxfordian to Tithonian, respectively (Fig. 17; Haq, 2018). Comparing the global eustatic cycles with the stratigraphical framework of the EKD (Fig. 15) allows identifying the respective influence of eustasy.

In the Kardeh area, the Chaman Bid-1 unit consists of an ammonite-rich condensed level, which is early Callovian in age. It is capping the uppermost part of the Kashafrud section, which also exhibits an ammonite-rich condensed level. These two condensed levels were probably the result of the $2^{\text {nd }}$ order eustatic sea-level rise lasting from the Bathonian to early Callovian (Haq, 2018) and of variations in the rate of subsidence. The regional onlapping surface at the base of Chaman Bid-1 (5 in Fig. 15) occurred within this $2^{\text {nd }}$ order sea-level rise. Therefore, it is interpreted as a structural-driven surface, whereas the condensed section at the transition between Chaman Bid-1 and the Khaneh Zou Fm. (Fig. 15) fits with the maximum of the eustatic sea-level rise (Fig. 17). The build-ups of the Khaneh Zou Fm. developed on top of rift-inherited blocks (Fig. 16) in a catchup mode. This is illustrated by the aggradation of the platforms during the Callovian to early 
Oxfordian time interval. The lack of obvious regressive trends and terrigenous input (their absence was identified from lithofacies analysis), despite the occurrence of a $2^{\text {nd }}$ order eustatic sea-level fall, could be interpreted as a subsidence effect masking the eustatic trend (black rectangle in Fig. 17). The bioclastic grainstones at the topmost part of the Khaneh Zou Fm. can be interpreted as sediments shed off the platform, deposited along the platform edge at the end of a $2^{\text {nd }}$ order highstand (Lasemi, 1995). These grainstones could also be part of an early transgression on top of a highstand (hydraulic dunes; Longhitano et al., 2014). Regardless of which interpretation is chosen, upper Oxfordian grainstones mark the turnover from the aggrading Callovian-lower Oxfordian mud-dominated build-ups to their flooding, represented by the Chaman Bid deep facies (Fig. 17). The fining upward trend of the Chaman Bid-2 unit (3 in Fig. 15) and the oncoid distribution (sensu Védrine et al., 2007) are consistent with the $2^{\text {nd }}$ order eustatic sea-level rise during the middle Oxfordian to Kimmeridgian, with maximum flooding at the end of the Kimmeridgian (RS50 in Figs. 15, 17). The rapid transition between the grainstones on the platform margin and hemipelagic mudstones of Chaman Bid-2 may be due to the enhancement of the eustatic rise by a combination of subsidence and the termination of carbonate production in deeper waters. In the proximal setting towards the southeast, the occurrence of fluvio-estuarine/deltaic strata (Fig. 15) is consistent with the middle Oxfordian to Kimmeridgian $2^{\text {nd }}$ order sea-level rise (Fig. 17). The maximum flooding surface at the end of the Kimmeridgian can be correlated to the peak of the eustatic rise in the late Kimmeridgian-early Tithonian interval (Haq, 2018). In the Tithonian Mozduran Fm., when the $2^{\text {nd }}$ order eustatic sea-level was falling, tubular sponge and coral mounds grew within progradational units, while argillaceous limestones and marls were deposited downslope. Based on the foraminifera records, Kalantari (1969) suggested a hiatus in the upper part of the Tithonian (in the Aghdarband area). In the field, it is hard to observe this hiatus in the siliciclastics of the Mozduran Fm. (2 in Fig. 15) but the occurrence of a hiatus is possible due to the lack of available accommodation space during this highstand period, when the newly produced oolitic sediments were shed downslope and the oolitic wedge prograded within the basinal mudstone. In addition, the increased energy level on the platform-top during lowstands produced erosion and transported the intraclasts downslope (Pomar, 2020). 


\subsection{Hydrocarbon exploration perspectives}

The Khaneh Zou Fm. may represent an attractive reservoir target for hydrocarbon exploration. Initially growing on top of a palaeo-high, the platform was subsequently drowned by the slope facies of the Chaman Bid-2 unit, which capped the Khaneh Zou Fm. as a top and lateral seal (onlapping pattern). During the development of bioclastic grainstones on top of the carbonate platform, coarse-grained calciturbidites were deposited in deeper parts of the basin; they are suggested as a secondary reservoir target. Concerning the source-rock potential, the hemipelagic sediment package capping the Khaneh Zou Fm. or occurring on the flank of the carbonate platform could have fed the reservoir through vertical or even lateral migration. Due to their geomorphology, such carbonate platforms provide lateral closure ( $c f$. Burgess et al., 2013). Their location above rift-inherited palaeo-highs suggests a preferred migration path from deeper source rocks such as those occurring in syn-rift Middle Jurassic siliciclastic strata.

\subsection{Comparison between the carbonate platforms in Iran and Turan areas}

Here, we investigate the possible synchronous deposition of the Middle to Upper Jurassic (MUJ) carbonate system in the Eastern Kopet Dagh (EKD) and in two close-by areas situated towards the northeast and southwest, respectively (Fig. 18). We start with comparing the southeastern and northeastern margins of the Amu Darya Basin, located in EKD (NE Iran) and southwestern Gissar (SE Uzbekistan; Fig. 1A), respectively. Subsequently, the EKD is compared to the Binalud Range forming the southern margin of the Kopet Dagh Basin, in continuation of the South Caspian Basin.

\subsubsection{Eastern Kopet Dagh vs. southwestern Gissar}

The MUJ carbonates of the Turan platform are exposed in the EKD and southwestern Gissar (Carmeille et al., 2018; Fürsich et al., 2017a). Both basins apparently evolved in a similar way during the Middle Jurassic to Early Cretaceous (Fig. 18). Carbonate production was initiated following the Middle Jurassic siliciclastic syn-rift phase.

In the EKD (e.g., Kardeh area), the two condensed levels, the Bathonian level on top of the siliciclastics of the Kashafrud Fm. and the lower Callovian level in the Chaman Bid-1 unit, represent a transgression (basinal setting) overlying the siliciclastic sediments. In the southwestern Gissar, the base of the Baysun Fm. is composed mainly of a condensed ammonite- and bivalverich unit that has been dated as middle Bathonian (Fürsich et al., 2017a). In both areas, siliciclastics 
are overlain by thick carbonate packages: the middle Callovian-Kimmeridgian? Kugitang Fm. in the southwestern Gissar (Carmeille et al., 2018) and the middle Callovian-Oxfordian Khaneh Zou Fm. in the EKD. In both areas, the post-rift sequence started in the Callovian: during or at the end of the early Callovian in the case of the southwestern Gissar (Brunet et al., 2017; Carmeille et al., 2018), when the siliciclastic content of the sediments decreased in the Baysun Fm., and during the Callovian in the case of the EKD, where it is marked by the end of terrigenous influx. A regional flooding occurred in the EKD during the early Callovian due to tectonic subsidence.

In the Kimmeridgian, the carbonate platform in the EKD did not keep up with the peak of the eustatic sea-level rise and eventually drowned (maximum flooding surface), as recorded by the slope to basinal facies of the Chaman Bid-2 unit. In the south-western Gissar, this maximum flooding surface is not well recognised and not represented by a sharp facies change (Carmeille et al., 2018). During the Late Jurassic, the Amu Darya basin was more restricted, while the Kopet Dagh was still open towards the South Caspian Basin (Barrier et al., 2018; Carmeille et al., 2018). The location of the Main Kopet Dagh fault is compatible with this palaeogeographic configuration shown in the Tithonian palaeotectonic map of Barrier et al. (2018) and this fault could have partially restricted the Amu Darya Basin from the southern, open-marine areas.

\subsubsection{Eastern Kopet Dagh and Binalud ranges}

The Binalud Range separates the EKD from the Central Iran basins (Fig. 1A). Located $80 \mathrm{~km}$ from the Kardeh area towards the SW, it is considered as the eastern extension of the Alborz Range along the Palaeotethys suture zone (cf. Wilmsen et al., 2009b; Zanchetta et al., 2013). Jurassic sedimentation in the Binalud Basin started with the Lower-Middle Jurassic Shemshak Group (Wilmsen et al., 2009). Fürsich et al. (2017b) interpreted the Binalud Range as part of the southern margin of a rift basin, which formed as the eastern extension of the South Caspian Basin. In the Binalud Range, following the Mid-Cimmerian Tectonic Event (Bajocian red unconformity in Fig. 18) the upper Bajocian transgression led to deposition of the Dalichai Fm. unconformably on top of the siliciclastics of the Shemshak Group (Fürsich et al., 2017b, 2009). In the EKD, the MidCimmerian unconformity is seen at the base of the Kashafrud Fm. (Noemani Rad et al., 2019; Taheri et al., 2009).

The lowest part of the Dalichai Fm. in the Binalud and eastern Alborz ranges (Fig. 1A) presents several condensed levels with red nodular limestones and marls ("Ammonitico Rosso" facies) of 
late Bajocian, Bathonian and Callovian ages (Parent et al., 2014; Raoufian et al., 2019; SeyedEmami et al., 2018). These condensed levels can be compared to the condensed levels which were observed in the Kardeh area in Bathonian and Callovian strata.

Based on stable isotope data $\left(\delta^{18} \mathrm{O}\right.$ and $\left.\delta^{13} \mathrm{C}\right)$, provided by Raoufian et al. (2019), the Mid to Late Jurassic seawater palaeo-temperature in the Binalud Range was about $26^{\circ} \mathrm{C}$. Together with the 28 ${ }^{\circ} \mathrm{C}$ for the Late Jurassic seawater temperature in the EKD (Mahboubi et al., 2010) it indicates a warm and subtropical climate for both areas. This is compatible with the palaeotectonic maps (Barrier et al., 2018) and the palaeoclimatic framework discussed in 8.2.2.

\section{Conclusions}

Throughout the Eastern Kopet Dagh, from the proximal part (southeast) towards the basin (northwestwards), the Callovian-Tithonian carbonates can be divided into two sequences. The first sequence, Callovian-early Oxfordian, consists of the Chaman Bid-1 unit and the Khaneh Zou Fm. The second sequence, late Oxfordian-Tithonian, involves the Chaman Bid-2 unit and the Mozduran Fm. The base of the carbonates (with a slope angle of $c a .2^{\circ}$ ) is characterised by the transgressive onlap of the marl-mudstones of the early Callovian Chaman Bid-1 unit. The Chaman Bid-1 unit has not been deposited or probably has been eroded in the proximal part (e.g., Shurijeh valley). At the Mozduran type locality, the thick basal dolomitic layer, corresponding to the innerplatform facies, changes northwestwards to the middle Callovian-lower Oxfordian muddominated build-ups of the Khaneh Zou Fm. (deposited in a mid-platform to upper slope system). The mud-dominated build-ups were growing during an aggrading to prograding trend. The highrelief mud-dominated carbonates of the platform did not contribute much to the shedding of carbonate material to the basin, except for some rare olistoliths interbedded within autochthonous hemipelagites deposited at the toe of slope and basin. At the platform margin, the upper Oxfordian bioclastic grainstones cap the build-ups. Some calciturbidites were probably fed from bioclastic grainstones. They were transported through upper slope gullies cutting the platform edge and interbedded between early cemented slumped cherty limestones. During the late OxfordianKimmeridgian, the inherited Callovian-Oxfordian morphology was onlapped by the Chaman Bid2 unit. The contact between Khaneh Zou Fm. and Chaman Bid-2 unit is characterised by the onlap terminations, indicating a diachronous surface. The onlap configuration with fining upward trend, bioclasts/oncoids content, as well as the eustatic sea-level rise indicate a transgressive trend during 
the late Oxfordian-Kimmeridgian period (deposition of Chaman Bid-2 unit). Towards the proximal part, the decrease of oncoid contents might indicate the back-stepping of the mid- and inner-platform facies. The drowning of the platform has been completed at the end of Kimmeridgian (maximum flooding surface, $\mathrm{mfs}$ ). This $\mathrm{mfs}$ is overlain by the downlaps of the Tithonian-early Berriasian oolitic prograding wedges. During a regressive trend, due to the lack of available accommodation space, the oolitic packstones and grainstones were shed downslope to intercalate within basinal mudstones. The reported Tithonian hiatus in the proximal part can be interpreted as a result of the increased energy level on the platform-top during regression that produced erosion and transport of intraclasts downslope. Northwestwards, in the Tithonian Mozduran Fm., tubular sponge and coral mounds grew within progradational units, while argillaceous limestones and marls were deposited downslope.

The new field observations and synthetic model, including the updated chronostratigraphic framework, suggest that the development of the carbonate platform in the Kopet Dagh Basin was controlled by (1) termination of rifting and subsequent transition to post-rift thermal subsidence, and by rift-inherited morphologies; (2) eustatic sea-level variations, as $2^{\text {nd }}$ order global sea-level trends can be correlated with the regional stratigraphic framework; (3) the hydrodynamic processes on the carbonate production systems leading to different carbonate assemblages and impacting carbonate platform morphology; (4) climatic changes due to the rapid latitudinal movement of the Iranian domain, allowing the development of prolific carbonate factories since the area experienced warm and arid climatic conditions during the Late Jurassic.

\section{Acknowledgment}

The authors are grateful to the National Iranian Oil Company, Exploration Directorate, for providing internal reports and invaluable help during fieldwork (NIOC-UPMC 161753C).

M.R. Majidifard and P. Courville are acknowledged for their help in fossil identification. Special thanks are due to M. Kavoosi, H. Dashtban, D. Morsalnejad, and L. Aghajari for their help in fieldwork. Many thanks to Y. Lasemi, and F. Amour for numerous suggestions that improved the original manuscript. The authors are indebted to reviewers Marco Brandano and Marcos Aurell for constructive comments that improved our manuscript significantly. The first author wishes to convey his appreciation to A. Lethiers (Sorbonne University) for carefully drafting several versions of some of the figures. 


\section{References}

Adabi, M.H., Ager, D. V, 1997. Late Jurassic brachiopods from north-east Iran. Palaeontology $40,355-362$.

Afshar-Harb, A., 1994. Geology of the Kopet-Dagh, Iran. Geological Survey of Iran, Tehran [In Persian].

Afshar-Harb, A., 1983. The geological map of the Sarakhs area; Scale 1:250000. National Iranian Oil Company, Tehran.

Afshar-Harb, A., 1979. The stratigraphy, tectonics and petroleum geology of the Kopet Dagh region, Northern Iran. (Doctoral dissertation). Imperial College London (University of London).

Aghaei, A., Zand-Moghadam, H., Moussavi-Harami, R., Mahboubi, A., 2018. Sequence stratigraphic analysis and sea-level history of the Upper Jurassic deposits (Mozduran Formation), south of Aghdarband, NE Iran. Hist. Biol. 2963, 1-19. https://doi.org/10.1080/08912963.2017.1421184

Al-Awwad, S.F., Pomar, L., 2015. Origin of the rudstone-floatstone beds in the Upper Jurassic Arab-D reservoir, Khurais Complex, Saudi Arabia. Mar. Pet. Geol. 67, 743-768. https://doi.org/10.1016/j.marpetgeo.2015.05.014

Alnazghah, M.H., Bádenas, B., Pomar, L., Aurell, M., Morsilli, M., 2013. Facies heterogeneity at interwell-scale in a carbonate ramp, Upper Jurassic, NE Spain. Mar. Pet. Geol. 44, 140-163. https://doi.org/10.1016/j.marpetgeo.2013.03.004

Alsharhan, A.S., 2014. Petroleum systems in the Middle East. In: Rollinson, H.R., Searle, M.P., Abbasi, I.A., Al-Lazki, A., Al Kindi, M.H. (Eds.), Tectonic Evolution of the Oman Mountains. Geol. Soc., London, Spec. Publ. 392, 361-408. https://doi.org/10.1144/SP392.19

Amante, C., Eakins, B.W., 2009. ETOPO1 1 Arc-Minute Global Relief Model: procedures, data sources and analysis. https://doi.org/10.7289/V5C8276M

Barrier, E., Vrielynck, B., Brouillet, J.F., Brunet, M.-F., (Contributors: Angiolini L., Kaveh F., 
Plunder A., Poisson A., Pourteau A., Robertson A., Shekawat R., Sosson M., and Zanchi, A.), 2018. Paleotectonic Reconstruction of the Central Tethyan Realm. TectononoSedimentary-Palinspastic maps from Late Permian to Pliocene. CCGM/ CGMW, Paris. http://www.ccgm.org. Atlas of 20 maps (scale: 1/15 000 000).

Bartolini, A., Pittet, B., Mattioli, E., Hunziker, J.C., 2003. Shallow-platform palaeoenvironmental conditions recorded in deep-shelf sediments: $\mathrm{C}$ and $\mathrm{O}$ stable isotopes in Upper Jurassic sections of southern Germany (Oxfordian-Kimmeridgian). Sediment. Geol. 160, 107-130. https://doi.org/10.1016/S0037-0738(02)00369-X

Berberian, M., King, G.C.P., 1981. Towards a paleogeography and tectonic evolution of Iran. Can. J. Earth Sci. 18, 210-265. https://doi.org/10.1139/e81-019

Bozorgi-Rad, B., Najafi, M., Mahboubi, A., Moussavi-Harami, R., Vahidinia, M., 2007. Revision on the age of Mozduran Formation in Khore syncline, north-east Mashhad, in: 11 th Symposium of the Geological Society of Iran. Ferdowsi University of Mashhad. Geol. Soc. Iran, Mashhad, pp. 1846-1853 [In Persian with English abstract].

Brigaud, B., Pucéat, E., Pellenard, P., Vincent, B., Joachimski, M.M., 2008. Climatic fluctuations and seasonality during the Late Jurassic (Oxfordian-Early Kimmeridgian) inferred from $\delta 180$ of Paris Basin oyster shells. Earth Planet. Sci. Lett. 273, 58-67. https://doi.org/10.1016/j.eps1.2008.06.015

Brunet, M.-F., Ershov, A. V., Korotaev, M. V., Melikhov, V.N., Barrier, E., Mordvintsev, D., Sidorova, I.P., 2017. Late Palaeozoic and Mesozoic evolution of the Amu Darya Basin (Turkmenistan, Uzbekistan). In: Brunet, M.-F., McCann, T., Sobel, E.R. (Eds.), Geological Evolution of Central Asian Basins and the Western Tien Shan Range. Geol. Soc., London, Spec. Publ., 427, 89-144. https://doi.org/10.1144/SP427.18

Brunet, M.-F., Shahidi, A., Barrier, E., Muller, C., Saïdi, A., 2010. South Caspian Basin opening: inferences from subsidence analysis in Northern Iran. In: Vining, B.A., Pickering, S.C. (Eds.), Petroleum Geology: From Mature Basins to New Frontiers-Proceedings of 7th Petroleum Geology Conference. Geol. Soc., London, 7, interactive DVD, Poster 1. https://doi.org/10.1144/0071245 
Buckman, S.S., 1909-1930. Yorkshire type ammonites. - 7 volumes, 773 pls; London (Wesley).

Burgess, P.M., Winefield, P., Minzoni, M., Elders, C., 2013. Methods for identification of isolated carbonate buildups from seismic reflection data. Am. Assoc. Pet. Geol. Bull. 97, 1071-1098. https://doi.org/10.1306/12051212011

Carmeille, M., Bourillot, R., Brunet, M.-F., Pellenard, P., Fürsich, F.T., Schnyder, J., Barrier, E., Blanpied, C., Sidorova, I.P., 2018. Architecture and sedimentary evolution of the southwestern Gissar carbonate platform (Uzbekistan) during the Middle-Late Jurassic. Mar. Pet. Geol. 97, 437-465. https://doi.org/10.1016/j.marpetgeo.2018.07.021

Carpentier, C., Martin-Garin, B., Lathuilière, B., Ferry, S., 2006. Correlation of reefal Oxfordian episodes and climatic implications in the eastern Paris Basin (France). Terra Nova 18, 191201. https://doi.org/10.1111/j.1365-3121.2006.00679.x

Colombié, C., Giraud, F., Schnyder, J., Götz, A.E., Boussaha, M., Aurell, M., Bádenas, B., 2014. Timing of sea level, tectonics and climate events during the uppermost Oxfordian (Planula zone) on the Iberian ramp (northeast Spain). Palaeogeogr. Palaeoclimatol. Palaeoecol. 412, 17-31. https://doi.org/10.1016/j.palaeo.2014.07.014

Cross, N.E., Bosence, D.W.J., 2008. Tectono-Sedimentary Models for Rift-Basin Carbonate Systems, in: Lukasik, J., Simo, J.A. (Eds.), Controls on Carbonate Platform and Reef Development. SEPM Spec. Publ. 89, 83-105. https://doi.org/https://doi.org/10.2110/pec.08.89.0083

Dromart, G., Garcia, J.P., Picard, S., Atrops, F., Lécuyer, C., Sheppard, S.M.F., 2003. Ice age at the Middle-Late Jurassic transition? Earth Planet. Sci. Lett. 213, 205-220. https://doi.org/10.1016/S0012-821X(03)00287-5

Embry, A.F., Klovan, J.E., 1971. A late Devonian reef tract on northeastern Banks Island, N.W.T. Bull. Can. Pet. Geol. 19, 730-781.

Flügel, E., 2010. Microfacies of Carbonate Rocks Analysis, Interpretation and Application, second. ed. Springer-Verlag, Berlin. https://doi.org/10.1007/10.1007/978-3-642-03796-2

Fürsich, F.T., Brunet, M.-F., Auxiètre, J.-L., Munsch, H., 2017a. Lower-Middle Jurassic facies patterns in the NW Afghan-Tajik Basin of southern Uzbekistan and their geodynamic 
context. In: Brunet, M.-F., McCann, T., Sobel, E.R. (Eds.), Geological Evolution of Central Asian Basins and the Western Tien Shan Range. Geol. Soc., London, Spec. Publ. 427, $357-$ 409. https://doi.org/10.1144/SP427.9

Fürsich, F.T., Wilmsen, M., Seyed-Emami, K., Majidifard, M.R., 2017b. Jurassic sedimentary environments of northern and east-central Iran: an overview, in: First International Congress on Jurassic of Iran and Neighboring Countries (ICJI). Mashhad, p. 6.

Fürsich, F.T., Wilmsen, M., Seyed-Emami, K., Majidifard, M.R., 2009. The Mid-Cimmerian tectonic event (Bajocian) in the Alborz Mountains, Northern Iran: evidence of the break-up unconformity of the South Caspian Basin. In: Brunet, M.-F., Wilmsen, M., Granath, J.W. (Eds.), South Caspian to Central Iran Basins. Geol. Soc., London, Spec. Publ., 312, 189203. https://doi.org/10.1144/SP312.9

Fürsich, F.T., Wilmsen, M., Seyed-Emami, K., Schairer, G., Majidifard, M.R., 2003. PlatformBasin Transect of a Middle to Late Jurassic Large-Scale Carbonate Platform System (Shotori Mountains, Tabas Area, East Central Iran). Facies 48, 171-198.

Ghasemi-Nejad, E., Kamali, M.R., Moussavi-Harami, R., Khavari-Khorasani, M.P., 2005. Palynology and Evaluation of Petroleum Potential Source of Chaman-Bid Formatiom (Upper Bajocian-Tithonian) in the Eastern Kopet-Dagh Basin, NE Iran. Iran. Int. J. Sci. 6, $61-72$.

Gill, G.A., Santantonio, M., Lathuilière, B., 2004. The depth of pelagic deposits in the Tethyan Jurassic and the use of corals: An example from the Apennines. Sediment. Geol. 166, $311-$ 334. https://doi.org/10.1016/j.sedgeo.2004.01.013

Hadavi, F., Khodadadi, L., 2014. Nannostratigraphy and palaeoecology of uppermost Mozduran Formation in the Kopeh-Dagh range (NE Iran). Arab. J. Geosci. 7, 1879-1889. https://doi.org/10.1007/s12517-013-0839-z

Haq, B.U., 2018. Jurassic Sea-Level Variations: A Reappraisal. GSA Today 28, 4-10. https://doi.org/10.1130/GSATG359A.1

Hernández-Molina, F.J., Fernández-Salas, L.M., Lobo, F., Somoza, L., Díaz-del-Río, V., Alveirinho Dias, J.M., 2000. The infralittoral prograding wedge: a new large-scale 
progradational sedimentary body in shallow marine environments. Geo-Marine Lett. 20, 109-117. https://doi.org/10.1007/s003670000040

Hosseiniyoon, M., Taheri, J., Azadbakht, S., Alavinejad, A., 2017. The Jurassic ammonites in the Koppeh Dagh tectono-sedimentary zone (NE Iran) based on Paleontological Archive Center, in: First International Congress on Jurassic of Iran and Neighboring Countries (ICJI). Geological Survey of Iran, Mashhad, p. 8 [In Persian with English abstract].

Hosseinyar, G., Moussavi-Harami, R., Abdollahie Fard, I., Mahboubi, A., Noemani Rad, R., 2019. Seismic geomorphology and stratigraphic trap analyses of the Lower Seismic geomorphology and stratigraphic trap analyses of the Lower Cretaceous siliciclastic reservoir in the Kopeh Dagh - Amu Darya Basin. Pet. Sci. https://doi.org/10.1007/s12182019-0347-1

Huber, H., Najmabadi, S., 1971. Geological Map of Hezar Masjid Area, SE Kopet Dagh Range (Northeast Iran), Scale 1:100000; GR. 329, National Iranian Oil Company. Tehran.

Insalaco, E., 1998. The descriptive nomenclature and classification of growth fabrics in fossil scleractinian reefs. Sediment. Geol. 118, 159-186. https://doi.org/10.1016/S00370738(98)00011-6

Insalaco, E., 1996. The use of late Jurassic coral growth bands as palaeoenvironmental indicators. Palaeontology 39, 413-431.

Jamali, A.M., 2011. Biostratigraphy and Lithostratigraphy of Lower Cretaceous Deposits in the East of Kopet Dagh (Doctoral dissertation). Faculty of Earth Sciences, Shahid Beheshti University [In Persian].

Kadivar, Z., Vahidinia, M., Mousavinia, A., 2017. Stratigraghy and Identifying Boundaries of Mozduran Formation with Magnetite Method in East Kopet-Dagh Basin. Int. J. Environ. Chem. Ecol. Geol. Geophys. Eng. 11, 555-561.

Kalantari, A., 1969. Foraminifera from the Middle Jurassic-Cretaceous Succession of KopetDagh Region (N.E. IRAN). NIOC, Geol. Lab. Publ. No. 3, Tehran.

Kauffman, E.G., Sohl, N.F., 1979. Rudists. In: Paleontology. Kluwer Academic Publishers, Dordrecht, pp 723-737. https://doi.org/10.1007/3-540-31078-9_123 
Kavoosi, M.A., 2010. Sedimentary environments and Sequence Stratigraphy of Upper Jurassic Deposits (Mozduran Formation) in the Eastern and Central areas of the Kopet Dagh Basin, NE Iran (Doctoral dissertation). Faculty of Sciences, Tarbiat Moallem University [In Persian].

Kavoosi, M.A., Lasemi, Y., Sherkati, S., Moussavi-Harami, R., 2009. Facies Analysis and Depositional Sequences of the Upper Jurassic Mozduran Formation, a Carbonate Reservoir in the Kopet Dagh Basin, NE Iran. J. Pet. Geol. 32, 235-260. https://doi.org/10.1111/j.17475457.2009.00446.x

Kent, D. V., Irving, E., 2010. Influence of inclination error in sedimentary rocks on the Triassic and Jurassic apparent pole wander path for North America and implications for Cordilleran tectonics. J. Geophys. Res. 115, 1-25. https://doi.org/10.1029/2009JB007205

Korte, C., Hesselbo, S.P., 2011. Shallow marine carbon and oxygen isotope and elemental records indicate icehouse-greenhouse cycles during the Early Jurassic. Paleoceanography 26, 1-18. https://doi.org/10.1029/2011PA002160

Lasemi, Y., 1995. Platform carbonates of the Upper Jurassic Mozduran formation in the Kopet Dagh Basin, NE Iran-facies, palaeoenvironments and sequences. Sediment. Geol. 99, 151164. https://doi.org/10.1016/0037-0738(95)00041-6

Leinfelder, R.R., Krautter, M., Laternser, R., Nose, M., Schmid, D.U., Schweigert, G., Werner, W., Keupp, H., Brugger, H., Herrmann, R., Rehfeld-Kiefer, U., Schroeder, J.H., Reinhold, C., Koch, R., Zeiss, A., Schweizer, V., Christmann, H., Menges, G., Luterbacher, H., 1994. The origin of Jurassic reefs: Current research developments and results. Facies 31, 1-56. https://doi.org/10.1007/BF02536932

Longhitano, S.G., Chiarella, D., Muto, F., 2014. Three-dimensional to two-dimensional crossstrata transition in the lower Pleistocene Catanzaro tidal strait transgressive succession (southern Italy). Sedimentology 61, 2136-2171. https://doi.org/10.1111/sed.12138

Lyberis, N., Manby, G., Poli, J.-T., Kalougin, V., Yousouphocaev, H., Ashirov, T., 1998. Posttriassic evolution of the southern margin of the Turan plate. Geodynamics 326, 137-143.

Madani, M., 1977. A Study of the Sedimentology, Stratigraphy and Regional Geology of the 
Jurassic Rocks of Eastern Kopet-Dagh, N.E. Iran. (Doctoral dissertation). Imperial College London (University of London).

Mahboubi, A., Moussavi-Harami, R., Carpenter, S.J., Aghaei, A., Collins, L.B., 2010.

Petrographical and geochemical evidences for paragenetic sequence interpretation of diagenesis in mixed siliciclastic-carbonate sediments: Mozduran Formation (Upper Jurassic), south of Agh-Darband, NE Iran. Carbonates and Evaporites 25, 231-246. https://doi.org/10.1007/s13146-010-0028-z

Majidifard, M.R., 2003. Biostratigraphy, Lithostratigraphy, ammonite taxonomy and microfacies analysis of the Middle and Upper Jurassic of northeastern Iran. (Doctoral dissertation). University of Würzburg.

Majidifard, M.R., Fürsich, F.T., Keupp, H., Seyed-Emami, K., 2017. Lower Tithonian ammonites from the Chaman Bid Formation in northeastern Iran, Koppeh-Dagh Basin. Geopersia 7, 11-26. https://doi.org/10.22059/geope.2017.212475.648265

Mattei, M., Muttoni, G., Cifelli, F., 2014. A record of the Jurassic massive plate shift from the Garedu Formation of central Iran. Geology 42, 555-558. https://doi.org/10.1130/G35467.1

Movahed, B., 1998. Lithology, depositional environments, regional distribution and reservoir properties of the Mozduran 1 and 2 and Chaman Bid formations in northeast of the KopetDagh (Doctoral dissertation). Islamic Azad University of North Tehran [In Persian].

Muttoni, G., Dallanave, E., Channell, J.E.T., 2013. The drift history of Adria and Africa from $280 \mathrm{Ma}$ to Present, Jurassic true polar wander, and zonal climate control on Tethyan sedimentary facies. Palaeogeogr. Palaeoclimatol. Palaeoecol. 386, 415-435. https://doi.org/10.1016/j.palaeo.2013.06.011

Muttoni, G., Kent, D. V., 2019. Jurassic Monster Polar Shift Confirmed by Sequential Paleopoles From Adria, Promontory of Africa. J. Geophys. Res. Solid Earth 3288-3306. https://doi.org/10.1029/2018JB017199

Muttoni, G., Mattei, M., Balini, M., Zanchi, A., Gaetani, M., Berra, F., 2009. The drift history of Iran from the Ordovician to the Triassic. In: Brunet, M.-F., Wilmsen, M., Granath, J.W. (Eds.), South Caspian to Central Iran Basins. Geol. Soc., London, Spec. Publ., 312, pp. $7-$ 
29. https://doi.org/10.1144/SP312.2

Nadjafi, M., Feyzi, A., Moussavi-Harami, R., 1999. Lithostratigraphy and Microfacies Analysis of Mozduran-1 Formation in North of Mashhad, Introducing Khaneh Zou Formation (Bathonian-Callovian). In: 3rd National Geoscience Congress. Geological Society of Iran, Shiraz, pp. 650-652 [In Persian].

Narani, H., Modjtahedi, A., Afrouz, F., 1968. Geological Report of Mozduran-Shuridjeh Area (North East of Mashhad). National Iranian Oil Company, Tehran.

Noemani Rad, R., Gharabeigli, G., Soleimany, B., 2017a. Half Graben Evolution in the Kopet Dagh Fold and Thrust Belt-Sedimentation and Paleo-Current History, in: Theme 9: Traps, Seals, Fault and Fracture Networks —Proceedings of the 2017- AAPG/SEG International Conference and Exhibition 100 Years of Science Fueling 100 Years of Prosperity. AAPG Datapages/Search and Discovery Article \#90310, London, p. 1.

Noemani Rad, R., Gorini, C., Ercilla, G., Do Couto, D., 2019. Seismic Facies Analysis of the Jurassic Syn-rift Marine Sediments in Eastern Kopet Dagh, NE Iran. In: Rebesco, M., Martorelli, E., Rooij, D. van, Hernandez-Molina, J., Davoli, G. (Eds.), 34th IAS Meeting of Sedimentology - Integrated Approaches to the Recognition of Contourite Depositional Systems. Roma.

Noemani Rad, R., Sherkati, S., Kavoosi, M.A., 2017b. Remaining Hydrocarbon Prospects in Eastern Kopet Dagh Basin, Northeastern Iran. In: Exploration Plays, Prospects, and Prospects Evaluation I—Proc. 79th EAGE Conf. \& Exhib. EarthDoc, EAGE, Paris, p. 5.

Olivier, N., Cariou, E., Hantzpergue, P., 2015. Evolution of a Late Oxfordian: early Kimmeridgian carbonate platform, French Jura Mountains. Swiss J. Geosci. 108, 273-288. https://doi.org/10.1007/s00015-015-0189-9

Parent, H., Raoufian, A., Seyed-Emami, K., Ashouri, A.R., Majidifard, M.R., 2014. The Bajocian-Kimmeridgian Ammonite Fauna of the Dalichai Formation in the SE Binalud Mountains, Iran. Inf. Inst. Fisiogr. Geol. 1, 1-115.

Pittet, B., Strasser, A., Mattioli, E., 2000. Depositional Sequences in Deep-Shelf Environments: a Response To Sea-Level Changes and Shallow-Platform Carbonate Productivity (Oxfordian, 
Germany and Spain). J. Sediment. Res. 70, 392-407. https://doi.org/10.1306/2DC409180E47-11D7-8643000102C1865D

Pomar, L., 2020. Carbonate Systems. In: Scarselli, N., Adam, J., Chiarella, D., Roberts, D.G., Bally, A.W. (Eds.), Regional Geology and Tectonics, Volume 1: Principles of Geologic Analysis. Elsevier B.V, pp. 235-312. https://doi.org/10.1002/9781444313710.ch10

Pomar, L., Aurell, M., Bádenas, B., Morsilli, M., Al-Awwad, S.F., 2015. Depositional model for a prograding oolitic wedge, Upper Jurassic, Iberian basin. Mar. Pet. Geol. 67, 556-582. https://doi.org/10.1016/j.marpetgeo.2015.05.025

Pomar, L., Kendall, C.G.S.C., 2008. Architecture of Carbonate Platforms: A Response to Hydrodynamics and Evolving Ecology. In: Lukasik, J., Simo, J.A. (Eds.), Controls on Carbonate Platform and Reef Development. SEPM Spec. Publ. 89, 188-216. https://doi.org/https://doi.org/10.2110/pec.08.89.0187

Pomar, L., Mateu-vicens, G., Morsilli, M., Brandano, M., 2014. Carbonate ramp evolution during the Late Oligocene (Chattian), Salento Peninsula, southern Italy. Palaeogeogr. Palaeoclimatol. Palaeoecol. 404, 109-132. https://doi.org/dx.doi.org/10.1016/j.palaeo.2014.03.023

Pomar, L., Molina, J.M., Ruiz-Ortiz, P.A., Vera, J.A., 2019. Storms in the deep: Tempestite- and beach-like deposits in pelagic sequences (Jurassic, Subbetic, South of Spain). Mar. Pet. Geol. 107, 365-381. https://doi.org/10.1016/j.marpetgeo.2019.05.029

Pomar, L., Morsilli, M., Hallock, P., Bádenas, B., 2012. Internal waves, an under-explored source of turbulence events in the sedimentary record. Earth-Science Rev. 111, 56-81. https://doi.org/10.1016/j.earscirev.2011.12.005

Raisossadat, S.N., Shokri, M.H., 2011. Biostratigraphic studies of the Lower Cretaceous (Upper Barremian - lower Aptian) Sarcheshmeh and Sanganeh Formations in the Kopet Dagh basin, NE Iran: an Integration of Calcareous Nannofossil and Ammonite Stratigraphies. Stratigr. Geol. Correl. 19, 188-204. https://doi.org/10.1134/S0869593811020109

Ramajo, J., Aurell, M., 2008. Long-term Callovian-Oxfordian sea-level changes and sedimentation in the Iberian carbonate platform (Jurassic, Spain): Possible eustatic 
implications. Basin Res. 20, 163-184. https://doi.org/10.1111/j.1365-2117.2007.00348.x

Raoufian, A., Zand-Moghadam, H., Seyed-Emami, K., 2019. Depositional history of MiddleUpper Jurassic succession at the Binalud mountains, NE Iran: implications of ammonite, trace fossil and stable isotopes in palaeoenvironmental analysis. Hist. Biol. 32, 1036-1053. https://doi.org/10.1080/08912963.2018.1563078

Ravnås, R., Steel, R.J., 1998. Architecture of marine rift-basin successions. Am. Assoc. Pet. Geol. Bull. 82, 110-146. https://doi.org/10.1306/1D9BC3A9-172D-11D7$8645000102 \mathrm{C} 1865 \mathrm{D}$

Robert, A.M.M., Letouzey, J., Kavoosi, M.A., Sherkati, S., Müller, C., Vergés, J., Aghababaei, A., 2014. Structural evolution of the Kopeh Dagh fold-and-thrust belt (NE Iran) and interactions with the South Caspian Sea Basin and Amu Darya Basin. Mar. Pet. Geol. 57, 68-87. https://doi.org/10.1016/j.marpetgeo.2014.05.002

Rogov, M.A., Zakharov, V.A., 2010. Jurassic and Lower Cretaceous glendonite occurences and their implication for Arctic paleoclimate reconstructions and stratigraphy. Earth Sci. Front. $17,345-347$.

Rowshanravan, J., Mafi, A., 2004. The geological map of the Mozduran area; Scale 1:100000, No. 8162 and 8262. Geological Society of Iran, Tehran.

Sajjadi, F., Hadad Tavakol, E., 2008. Palynomorph-Based Palaeoecology of the Kashafrud Formation, Eastern Mashhad, Koppeh-Dagh. J. Sci. (Univ. Tehran) 34, 85-101 [In Persian].

Schlager, W., Reijmer, J.J.G., Droxler, A., 1994. Highstand Shedding of Carbonate Platforms. J. Sediment. Res. B64, 270-281. https://doi.org/10.1306/D4267FAA-2B26-11D7$8648000102 \mathrm{C} 1865 \mathrm{D}$

Schlagintweit, F., Kadivar, Z., Rashidi, K., 2019. Some Microfossils (Dasycladales, Benthic Foraminifera, Sponges) from the Upper Jurassic Mozduran Formation (NE Iran, KopetDagh) and their Biostratigraphic and Palaeobiogeographic Importance. Riv. Ital. Paleont. Stratigr. 125, 317-331. https://doi.org/10.3390/molecules23061257

Seilacher, A., 1977. Pattern analysis of Paleodictyon and related trace fossils. In: Crimes, T.P., Harper, J.C. (Eds.), Trace Fossils 2. Geol. Journal Spec. Issue 9, 289-334. 
Sellwood, B.W., Valdes, P.J., 2008. Jurassic climates. Proc. Geol. Ass. 119, 5-17. https://doi.org/10.1016/S0016-7878(59)80068-7

Senowbari-Daryan, B., Bucur, I.I., Schlagintweit, F., Săsăran, E., Matyszkiewicz, J., 2008. Crescentiella, a new name for "Tubiphytes" morronensis CRESCENTI, 1969: An enigmatic Jurassic-Cretaceous microfossil. Geol. Croat. 61, 185-214. https://doi.org/10.4154/GC.2008.17

Seyed-Emami, K., Raoufian, A., Zand-Moghadam, H., 2018. Late Bajocian and Bathonian (Middle Jurassic) ammonites from the Dalichai Formation north of Damghan (Alborz, North Iran). N. Jb. Geol. Paläont., Abh. 288, 183-203. https://doi.org/10.1127/njgpa/2018/0732

Seyed-Emami, K., Schairer, G., Majidifard, M.R., Mohammadi-Monfared, M., 1999. First record of Lower Tithonian in the Chaman Bid Formation at the type locality near Bash Kalateh (Central Koppeh Dagh, NE Iran). Mitt. Bayer. Staatss. Paläont. Hist. Geol. 39, 21-32 [In German with English abstract].

Seyed-Emami, K., Schairer, G., Raoufian, A., Shafeizad, M., 2012. Middle and Late Jurassic ammonites from the Dalichai Formation west of Shahrud (East Alborz, North Iran). N. Jb. Geol. Paläont. Abh. 267, 43-66. https://doi.org/10.1127/0077-7749/2012/0296

Sha, J., Cestari, R., Fabbi, S., 2020. Paleobiogeographic distribution of rudist bivalves (Hippuritida) in the Oxfordian-early Aptian (Late Jurassic-Early Cretaceous). Cretac. Res. 108, 104289. https://doi.org/10.1016/j.cretres.2019.104289

Shahidi, A., 2008. Tectonic evolution of Northern Iran (Alborz and Kopet Dagh) since Mesozoic (Doctoral dissertation). Université Pierre et Marie Curie, Paris [In French].

Sharland, P.R., Archer, R., Casey, D.M., Davies, R.B., Hall, S.H., Heward, A.P., Horbury, A.D., Simmons, M.D., 2001. Arabian Plate Sequence Stratigraphy. GeoArabia Spec. Publ. 2, 371.

Skelton, P.W., Smith, A.B., 2000. A preliminary phylogeny for rudist bivalves: sifting clades from grades. In: Harper, E.M., Taylor, J.D., Crame, J.A. (Eds.), The Evolutionary Biology of the Bivalvia. Geol. Soc., London, Spec. Publ. 177, 97-127. https://doi.org/10.1144/GSL.SP.2000.177.01.06 
Taheri, J., Fürsich, F.T., Wilmsen, M., 2009. Stratigraphy, depositional environments and geodynamic significance of the Upper Bajocian-Bathonian Kashafrud Formation, NE Iran. In: Brunet, M.-F., Wilmsen, M., Granath, J.W. (Eds.), South Caspian to Central Iran Basins. Geol. Soc., London, Spec. Publ. 312, 205-218. https://doi.org/10.1144/SP312.10

Torsvik, T.H., Van der Voo, R., Preeden, U., Mac Niocaill, C., Steinberger, B., Doubrovine, P. V., van Hinsbergen, D.J.J., Domeier, M., Gaina, C., Tohver, E., Meert, J.G., McCausland, P.J.A., Cocks, L.R.M., 2012. Phanerozoic Polar Wander, Palaeogeography and Dynamics. Earth-Sci. Rev. 114, 325-368. https://doi.org/10.1016/j.earscirev.2012.06.007

Ulmishek, G.F., 2004. Petroleum Geology and Resources of the Amu-Darya Basin, Turkmenistan, Uzbekistan, Afghanistan, and Iran. U.S. Geol. Surv. 2201-H.

Védrine, S., Strasser, A., Hug, W., 2007. Oncoid growth and distribution controlled by sea-level fluctuations and climate (Late Oxfordian, Swiss Jura Mountains). Facies 53, 535-552. https://doi.org/10.1007/s10347-007-0114-4

Wilmsen, M., Fürsich, F.T., Taheri, J., 2009. The Shemshak Group (Lower-Middle Jurassic) of the Binalud Mountains, NE Iran: stratigraphy, depositional environments and geodynamic implications. In: Brunet, M.-F., Wilmsen, M., Granath, J.W. (Eds.), South Caspian to Central Iran Basins. Geol. Soc., London, Spec. Publ. 312, 175-188. https://doi.org/10.1144/SP312.8

Zanchetta, S., Berra, F., Zanchi, A., Bergomi, M., Caridroit, M., Nicora, A., Heidarzadeh, G., 2013. The record of the Late Palaeozoic active margin of the Palaeotethys in NE Iran: Constraints on the Cimmerian orogeny. Gondwana Res. 24, 1237-1266. https://doi.org/10.1016/j.gr.2013.02.013

Zand-Moghadam, H., Moussavi-Harami, R., Mahboubi, A., Aghaei, A., 2016. Lithofacies and sequence stratigraphic analysis of the Upper Jurassic siliciclastics in the eastern KopetDagh Basin, NE Iran. J. African Earth Sci. 117, 48-61. https://doi.org/10.1016/j.jafrearsci.2016.01.021

Zheng, R., Li, Y., Wu, L., Wu, X., Li, F., Niu, G., 2011. Geochemical characteristics of Callovian-Oxfordian carbonates in Samandepe gas field, Amu Darya Basin, Turkmenistan. 
Pet. Sci. 8, 371-381. https://doi.org/10.1007/s12182-011-0155-8

Table Captions

Table 1. Main lithofacies of different types of the Callovian-Tithonian carbonate system in Eastern Kopet Dagh.

Table 2. Selected biostratigraphic data (Middle-Late Jurassic) located in Fig. 15 and compiled from this study and previous publications across the Kopet Dagh Basin. Suggested age of the formations: Kashafrud: late Bajocian-Bathonian; Chaman Bid-1: early Callovian; Khaneh Zou: middle Callovian-late Oxfordian; Chaman Bid-2: late Oxfordian-Kimmeridgian (the base of Chaman Bid-2 is a diachronous surface depending on the onlapping onto the Khaneh Zou); Mozduran: Tithonian.

\section{Figure Captions}

Fig. 1. A) Inset topographic map showing the major structures of NE Iran and surrounding areas; modified from ETOPO1 (Amante and Eakins, 2009). PTSZ, Palaeotethys Suture Zone; the location of which is often not well determined. The white-dashed rectangle shows the location of Fig. 1B. B) Geological map of the Eastern Kopet Dagh (EKD), modified after Kavoosi (2010) superimposed on NASA's ASTER Global Digital Elevation Model (ASTGTM). The black rectangle denotes the geological map of the Kardeh area, shown in Fig. 5. The crooked white line refers to the interpretative transect in Fig. 15.

Fig. 2. Chronostratigraphic chart (Upper Triassic-Lower Cretaceous) of the EKD, indicating the major regional tectonic events (Afshar-Harb, 1994; Brunet et al., 2017; Jamali, 2011; Raisossadat and Shokri, 2011; Robert et al., 2014) and the findings reported in the present study. The Bathonian to Early Cretaceous biostratigraphy has been constructed based on ammonite datings in this study and on a compilation of published data (see Table 2 for more details).

Fig. 3. Pre-Campanian synthetic stratigraphic transect, from the Shurijeh valley to Taher Abad, modified after Afshar-Harb (1979). For the location of the stratigraphic sections see Fig. 1. In the easternmost part of the section (Shurijeh valley), the siliciclastic sediments of the Jurassic Mozduran Fm. (sensu lato) change to progressive progradation of platforms carbonates (Khaneh Zou Fm.) and time-equivalent hemipelagic facies of the Chaman Bid Fm. (dark blue). The age of 
the Shurijeh, Tirgan, Sarcheshmeh, and Sanganeh formations is Early Cretaceous and that of the Aitamir, and Abderaz formations is Late Cretaceous. For the ammonite content refer to the text. The inclination of the slope $(\beta)$ is about 2 degrees, estimated by the surface stratigraphic logs of NIOC.

Fig. 4. A) Google Earth satellite image of the Ghorghoreh area (for location see Fig. 1B) showing the geometry of reference surfaces (RS). The reference surfaces were identified and used to define the general stratigraphic framework of the study area (Fig. 15). RS70, Top Shurijeh; RS55/60, Top Mozduran Fm. (sensu stricto); RS50, Top Chaman Bid-2 unit; RS40, Top Khaneh Zou Fm.; RS32, Top massive dolomitic part of Khaneh Zou Fm.; RS30, Top Chaman Bid-1 unit; RS20, Top Kashafrud Fm. White arrows show the onlap of the Chaman Bid-1 and Chaman Bid-2 units onto the Kashafrud and Khaneh Zou formations, respectively. Toplap terminations of the Kashafrud Fm. (red arrow; southeast of the Ghorghoreh locality) mark an emersion. Red rectangle shows the framework of Fig. 11. B) Schematic sedimentological logs (Narani et al., 1968) along the Mozduran Ridge correlated by the reference surfaces on the satellite images. The stratigraphic sections range from proximal (Shurijeh) to distal (Sirzar).

Fig. 5. Geological map of the Kardeh area, north of Mashhad, NE Iran. The location is shown in Fig. 1B. Jksh, Kashafrud Fm.; JKhZ, Khaneh Zou Fm. showing the geometry of the Kardeh platform; JChB, Chaman Bid Fm. (Chaman Bid-1 and Chaman Bid-2 units); JMz, Mozduran Fm.; KSj, Shurijeh Fm.; Ngr, Red Neogene series; PLQc, Pliocene Conglomerate; Qt, Quaternary deposits. The Chaman Bid facies were found to be onlapping onto and infilling the existing topography of the platform facies (black arrows). On the southern flank of the Kardeh anticline, the thickness of the Chaman Bid-2 unit varies from $1468 \mathrm{~m}$ (along sites B-C) to $486 \mathrm{~m}$ southeastwards. On the northern flank, the thickness was estimated to be $850 \mathrm{~m}$ at site A and increased southeastwards to $1028 \mathrm{~m}$ along section G-F. On the southern flank of the anticline, the Khaneh Zou Fm. exhibits a maximum NW-SE extension of $c a .23 \mathrm{~km}$. Its thickness is $c a .600 \mathrm{~m}$ (site E) and is decreasing eastwards to $c a .200 \mathrm{~m}$. The green lines in the Khaneh Zou Fm. illustrate off-platform shedding sediments (grainstones) on the southern flank of the anticline, which disappear towards the east and west. Sedimentological logs in Fig. 7A have been measured on the northern (G, F, and H) and southern flank (B and E) of the Kardeh anticline. 
Fig. 6. Observed structural and stratal patterns on the Kardeh anticline. A) Sites D, E, and G exhibiting chevron fold set (dashed white lines) in the siliciclastic storm-wave-dominated facies of the Kashafrud Fm. A NE-verging reverse fault (dashed red line) is interpreted as passing through the Kashafrud Fm. along the anticline axis, striking in the same direction as the chevron fold set. RS30 is a faulted layer contact that can be followed along the Kardeh anticline, the so-called Kardeh fault. B) Panorama photograph taken from the site E, view towards the north, exhibiting Kashafrud, Chaman Bid-1 and Khaneh Zou formations on the northern flank of the anticline. Black arrow shows truncations at the basal Khaneh Zou Fm. in the west, allowing identification of a gully-like feature striking towards the North. C) Panoramic view from the site $\mathrm{C}$ across the complete Jurassic succession.

Fig. 7A. Measured sedimentological logs on the northern (G, F, and H) and southern flanks (B and E) of the Kardeh anticline. The sites and Reference Surfaces (RS) are shown in Fig. 6.

Fig. 7B. Legend for the sedimentological logs shown in Fig. 7A and block diagrams in Fig. 16.

Fig. 8. Lithofacies and sedimentary structures of the siliciclastic sediments of the Mozduran Fm. A) Detailed view of planar cross-bedded sandstones and herringbone cross-bedding (Shurijeh valley locality). B) Bedding-plane view of a sandstone bed with asymmetric ripples on topmost part of the Mozduran Fm. (Hammam Qaleh locality).

Fig. 9. From mud-dominated build-ups to off-platform shedding grainstones; the southern flank of the Kardeh anticline at site I. A) Panoramic view showing southward-directed small-scale clinoforms (wedge-shaped dashed lines) composed of bioclastic grainstones at the cliff crest, overlying Recent travertines on the flank. Local occurrence of coral-bearing mounds was observed (dashed circle), interbedded within grainstone facies. The angles are unfolded. The black arrow points to a 2-m scale. B) Unsorted grainstones with large thick-shelled bivalves (diceratids?) on top of the platform. C) Dolomite occurs repeatedly on vertical N10-oriented fractures cutting through the grainstones. These fracture-related dolomites are decimetric to metric in thickness and can be followed for several metres in the form of aligned lenses and patches. D) Centimetre-thick zebra-like patches occurring locally in the dolomitised mixstone on the front quarry. E) Domestone with stromatactis-like structures and thrombolitic mudstones. F) Dm-sized bush-like colonial 
organisms (black arrow; corals?). G) Discontinuous mixstone with decimetric colonial organisms and large cone-shaped bivalves (black arrow).

Fig. 10. Facies of the Khaneh Zou Fm. in the Handel Abad section (for location see Fig. 1B). A) Platestone of platy corals. B) Coral pillarstone with wackestone matrix. C) Stromatactis-like fabric. D) Zebra/stromatactis-like fabric. E) Solitary corals. F) An early diagenetic cavity, partially with a geopetal fill of calcareous mud and calcite. (G) Nerineid floatstone. H, I) Shelly coarse grainstone with fragments and complete valves of large thick-shelled recrystallised bivalves (including diceratids?), occurring at the top of the formation.

Fig. 11. Ghorghoreh locality (red rectangle in Fig. 4), showing different Middle to Upper Jurassic depositional environments. A) RS20 represents the top of the Kashafrud Fm., RS30 is the top of the Chaman Bid-1 unit onlapping onto the Kashafrud Fm.; RS32 represents the Khaneh Zou type facies (floatstone/rudstone and platestone to mixstone), and RS40 is top of the off-platform grainstone and calciturbidites of the Khaneh Zou Fm. B) Tentative interpretation of the geometries observed from the satellite image; analysis based on field observations and sedimentological logs measured by Kavoosi et al. (2009) and Narani et al. (1968). C) Slope carbonates are composed of mass transport deposits (MTDs) or slumps of cherty limestones and clinoforms of calciturbidites. D) Platform carbonates are composed of build-ups and grainstones showing evidence of erosional scars (red lines).

Fig. 12. Mounds with reworked flank deposits; Mozduran Fm., northern and southern flanks of the Kardeh anticline, at sites F and B, respectively. A) Mounds within the Mozduran Fm.: plurimetric units with massive core and well-bedded flanks. B) Mixstone of tubular sponges overlain by stromatolite (arrowed) with wackestone matrix. C, D) Exotic block including a tilted coral bouquet (D). Dissolved corals within a cemented matrix (site B in Fig. 5). E) Coral bouquet in growth position (pillarstone sensu Insalaco, 1998) at the base of a mound.

Fig. 13. Gravity deposits on the northern flank of the Kardeh anticline, site D in Fig. 5. A) Slope deposits: at the top of the coarse grainstone cliff a several-m-thick calciturbidite rests, with a sharp contact (red dashed line), on dm-thick mudstones/wackestones with ammonites and chert nodules. The beds have been deformed (dashed black lines) by abrupt deposition of the overlying turbidite. B) Thick upward-fining turbidite bed; arrow indicates a continuous nodular chert level. C) Detail 
of convolute bedding observed at the top of the underlying finer-grained sediments (black arrow).

D) Cm-thick, fine-grained bioclastic turbidites, intercalated between bioturbated marl/mudstones.

E) Plan view of an endogenic irregular burrow network.

Fig. 14. Basinal deposits with intercalation of gravity deposits, northern and southern flanks of the Kardeh anticline. A) Hemipelagic limestones of the Chaman Bid-2 unit (northern flank of Kardeh anticline, site H). B) Hemipelagic limestones (Chaman Bid-2 unit) with limestone block cutting the underlying beds (arrowed) and capped by overlying beds with an onlap geometry, arguing for syn-sedimentary gravitational deposition (site B in Fig. 5). C) Hemipelagic limestones (Chaman Bid-2 unit) with an intercalated lens of bioclastic grainstone-rudstone with an erosional base (arrowed), corresponding to the intercalation of a gravity deposit within the hemipelagic background sedimentation (site B in Fig. 5). D) Hemipelagic limestones (Chaman Bid-2 unit) with interbedded olistolith composed of black mudstone (site G in Fig. 5). E) Large oncoids in the rudstone lens shown in C. F). Reworked brachiopod grainstone-rudstone lens shown in C.

Fig. 15. Stratigraphic and depositional model for the Eastern Kopet Dagh (from Shurijeh valley to Kardeh localities). For localities refer to Fig. 1B. SHJ, Shurijeh valley; MOZ, Mozduran; BAZ, Bazangan; GPL, Gas Pipeline; HA, Handel Abad; OK, Ortakand; HQ, Hammam Qaleh; KD, Kardeh. In the eastern part of the study area, where the Chaman Bid-1 unit is absent, the Mozduran Fm. (sensu lato) is composed of units 1 and 2. Towards the northwest, unit 2 refers to the Mozduran Fm. (sensu stricto). Data: (1) Outcrop sections measured in this study and also presented in Narani et al. (1968) are calibrated with observations on satellite images using Reference Surfaces RS1060 (Fig. 4). The slope of the carbonate platform is about 2 degrees, measured by the stratigraphic logs presented in Narani et al. (1968). (2) Biostratigraphy compiled from this study and other authors (see Table 2), based on ammonites (A), foraminifers (f), brachiopods, pollen, spores, and Dasycladales.

Fig. 16. Stages in the depositional evolution at the Kardeh area from the late Bajocian (A) to Tithonian (F). The block diagrams illustrate the approximate palaeogeography during the various time slices. For the main bioclastic and non-bioclastic elements, refer to the legend in Fig. 7B. 3: Mud-dominated carbonates containing serpulids, corals, stromatactis-like structures; platform margin probably supplying the olistoliths intercalated between marl along the slope and towards the surrounding basin. 4 and 5: High-energy platform margin deposits, grainstone facies with sand 
waves, developing on top of the platform facies, probably feeding turbiditic grainstones to the slope and the surrounding basin through upslope gullies. 6: Lower slope to basinal marl/mudstones with ammonites (condensed section; Chaman Bid-1 unit), ending Kashafrud deposition. 7: Hemipelagic mudstones and marl, with rare intercalation of gravity deposits (calciturbidites; Chaman Bid-2 unit); slope to basinal setting. 8: Shaly limestones with isolated small tubular sponge and coral-bearing mounds, downslope gradational to the Chaman Bid facies.

Fig. 17. Factors controlling the sedimentary model.

Fig. 18. Comparison of the Middle-Upper Jurassic (MUJ) succession of three regions from south to north: Binalud Range, Eastern Kopet Dagh (EKD), and SW Gissar in the Amu Darya Basin $(\mathrm{ADB})$. 


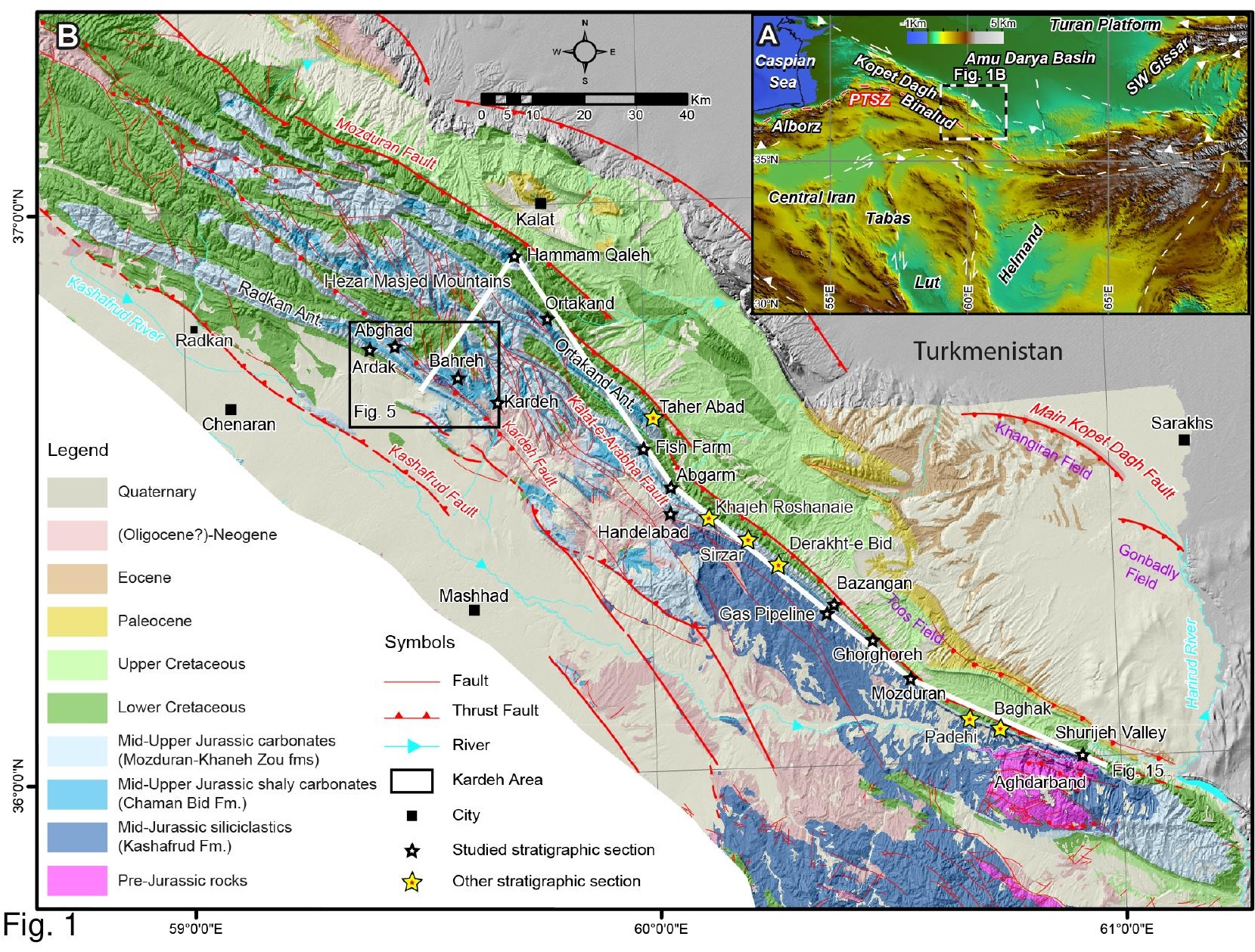




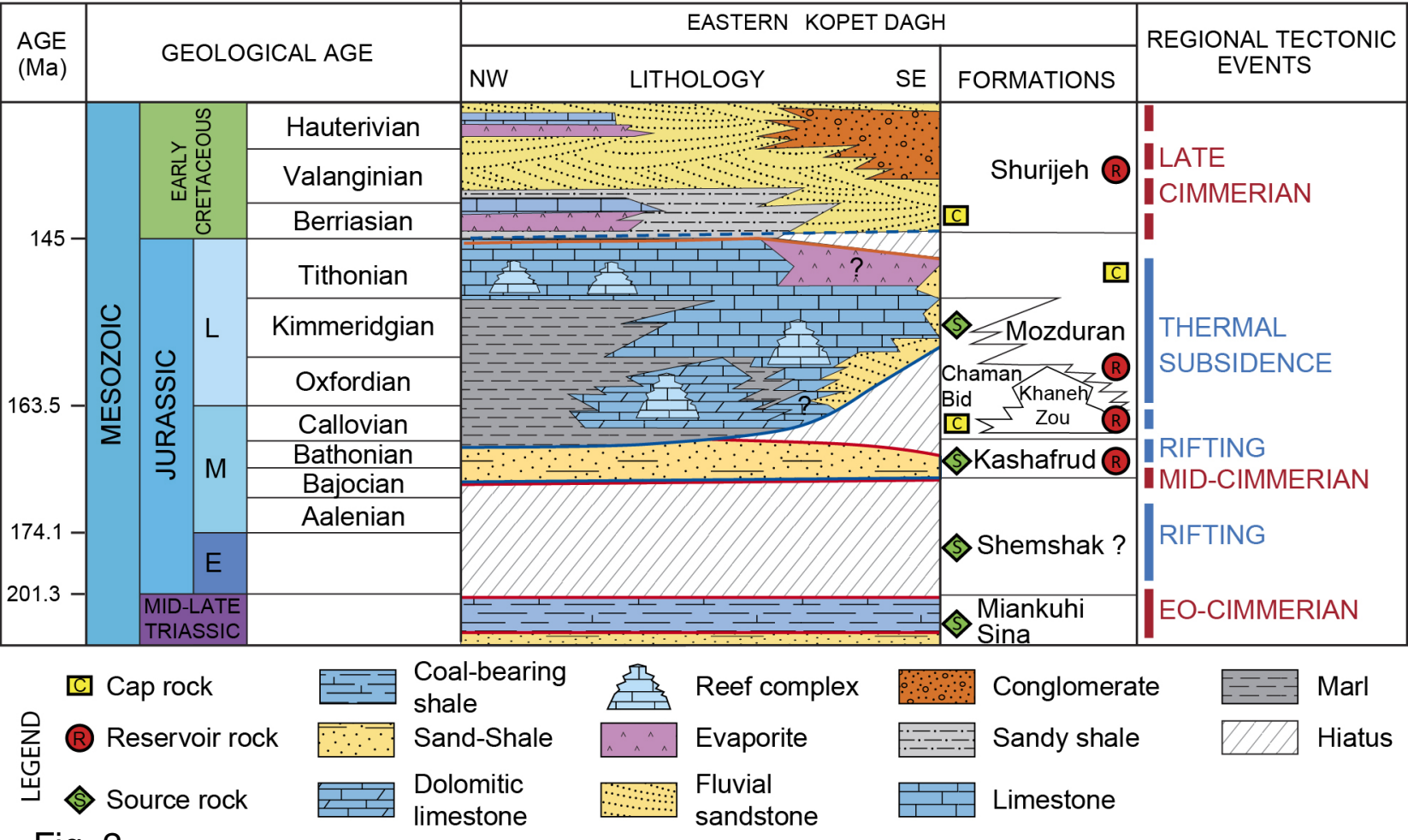

Fig. 2 


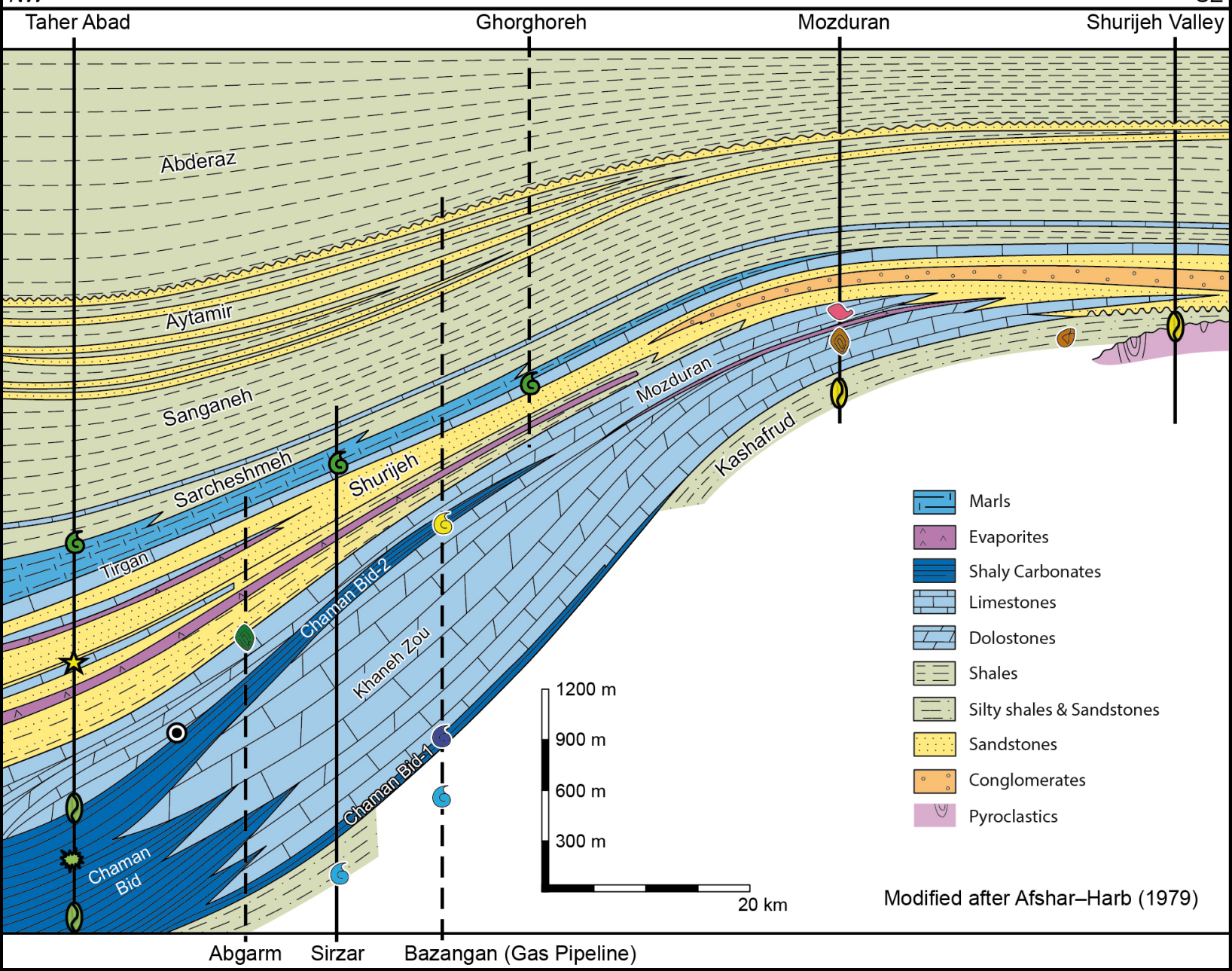

\section{Biostratigraphy}

6. Ammonites (Early Aptian)- from Raisossadat and Shokri (2011)

(6) Ammonites (Richterella richteri: early Tithonian) - from Hosseiniyoon et al. (2017)

Ammonites (Macrocephalites: Callovian) - from Taheri et al. (2009)

Ammonites (Garantiana and Parkinsonia zones: late Bajocian) - from Hosseiniyoon et al. (2017)

Foraminifers (Anchispirocyclina lusitanica: Tithonian-early Berriasian)

Foraminifers (Alveosepta jaccardi: Oxfordian-Kimmeridgian) - from Kadivar et al. (2017)

Brachiopods (Moeschia, Uralella, Torquirhynchia: early Tithonian) - from Adabi and Ager (1997)

O Dasycladales (Campbelliella striata, Montenegrella florifera, Petrascula bugesiaca, Triploporella sp.: Tithonian) - from Schlagintweit et al. (2019)

Nannofossils (Berriasian-Valanginian) - from Hadavi and Khodadadi (2013), Bozorgi-rad (2007)

(1) Pollen \& Dinoflagellates (Mid-Late Jurassic) - from Ghasemi-Nejad et al. (2005)

Pollen (Early - Mid Jurassic) - from Madani (1977)

Spore (Contignisporites burgeri: late Bajocian-early Bathonian) - from Sajjadi and Hadad Tavakol (2008)

Fig. 3 


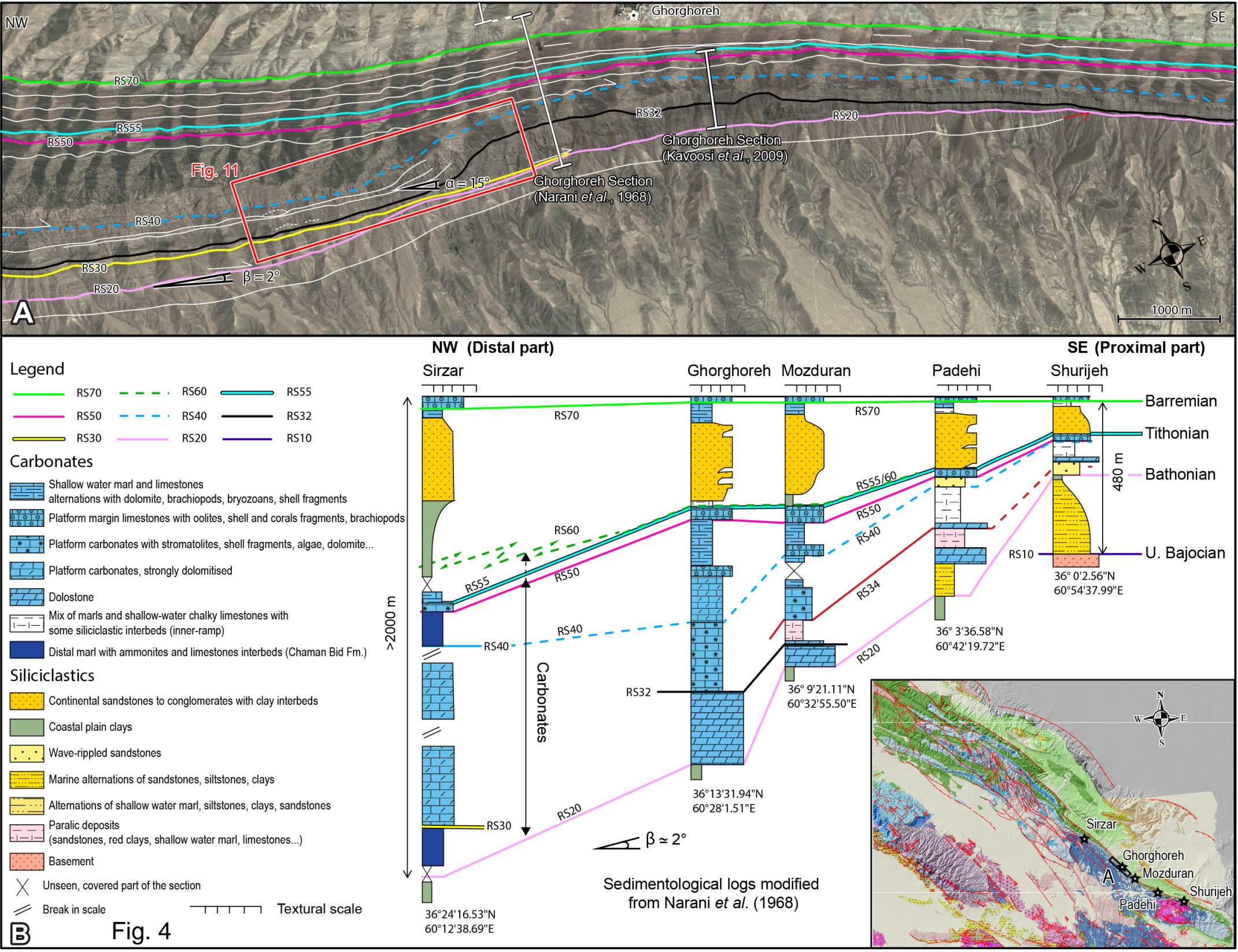




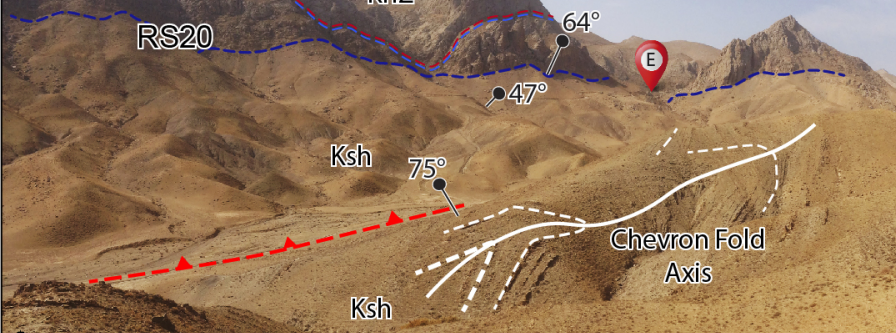

(D),

\section{SW}

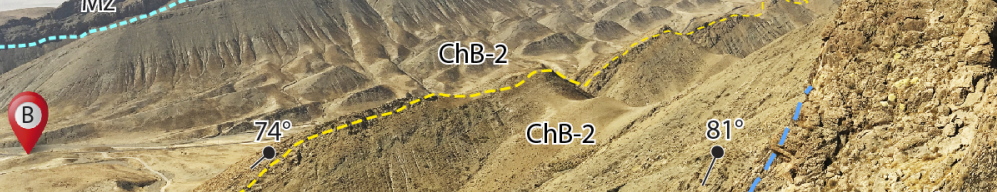

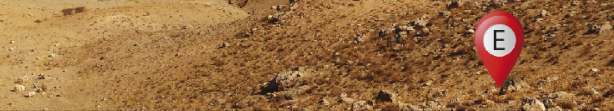

A 13

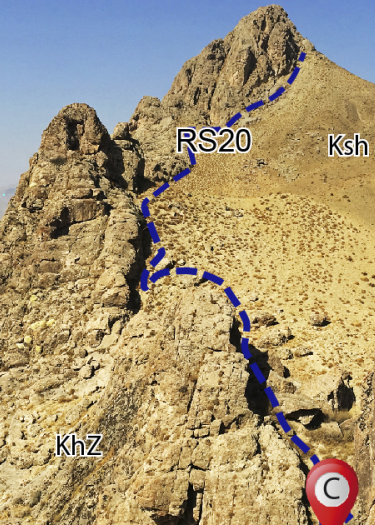

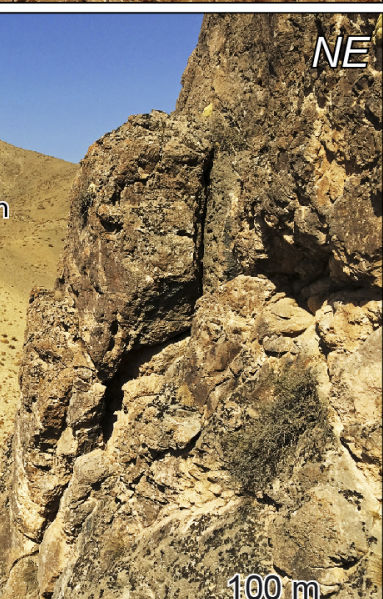

Fig. 6 RS40 


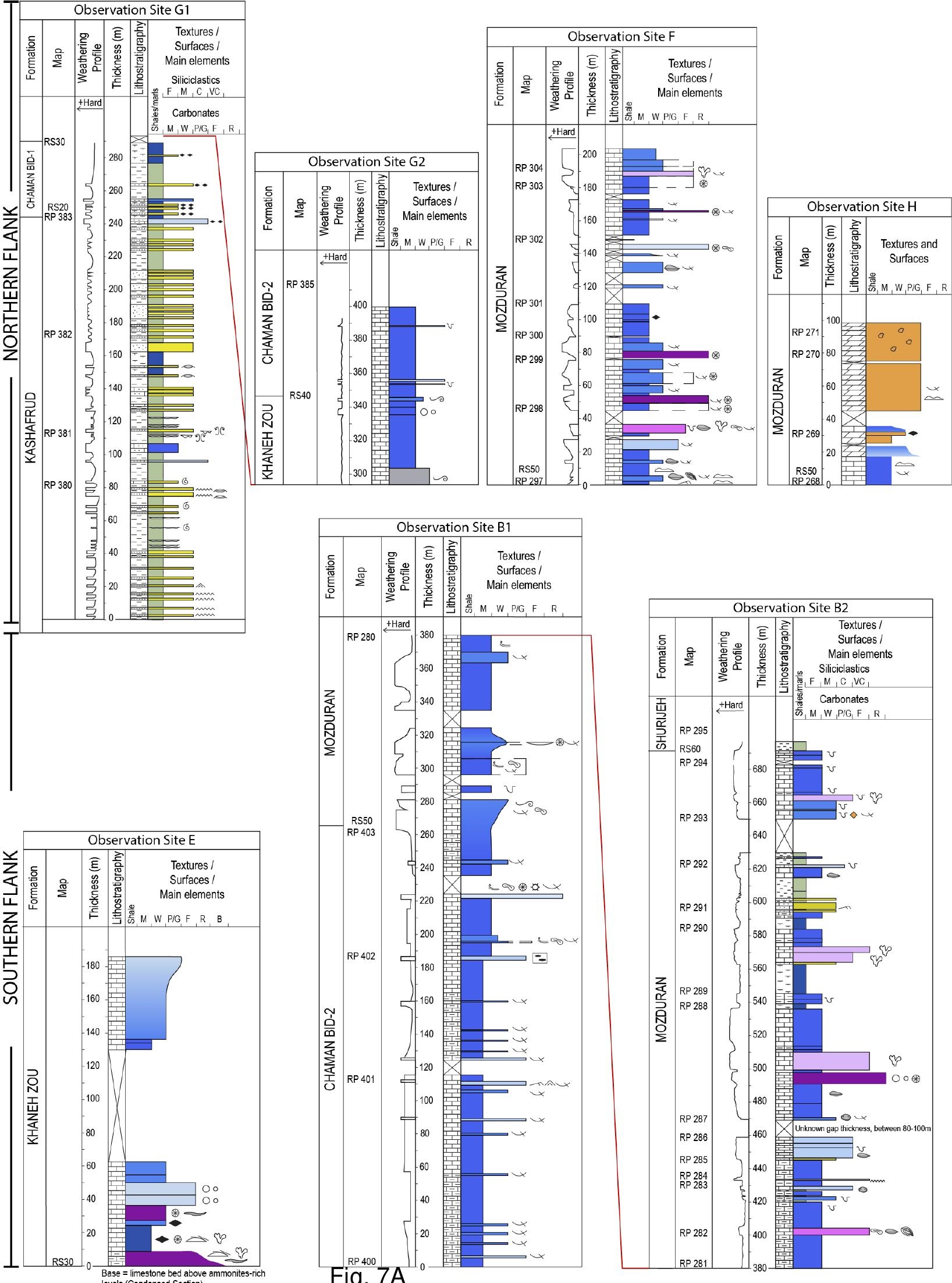




\section{- LITHOSTRATIGRAPHY -}

LITHOLOGY COLUMN

\begin{tabular}{|c|c|}
\hline \begin{tabular}{|l|l|} 
& 1 \\
& \\
\end{tabular} & Limestone (Lmst) \\
\hline \begin{tabular}{|l|}
1 \\
\end{tabular} & Dolomitic Lmst \\
\hline$B, B$ & Dolostone \\
\hline 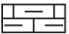 & Shaly Lmst \\
\hline
\end{tabular}

\begin{tabular}{|c|c|}
\hline- & Shale \\
\hline$T_{T}$ & Marl \\
\hline $\begin{array}{l}\because \dot{ } \\
\end{array}$ & $\begin{array}{l}\text { Sandstone } \\
\text { (with calcareous cement) }\end{array}$ \\
\hline$\because \because$ & Sandstone \\
\hline
\end{tabular}

COLOURS ON TEXTURAL LOGS

LIMESTONES:

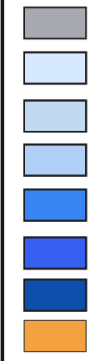

Slumps

Rudstone

Floatstone

Packstone / Grainstone

Wackestone

Mudstone

Marl

Dolostone

\section{SILICICLASTICS:}

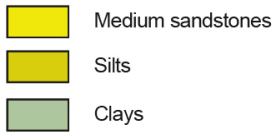

BIOCONSTRUCTION FACIES:

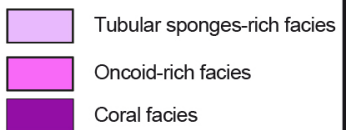
OTHER:

X Recristallised limestone

- TEXTURES -

$\mathrm{S}$
$\mathrm{F}$
$\mathrm{M}$
$\mathrm{C}$
$\mathrm{V}$

SILICICLASTICS:

F $\quad$ Fine

M Medium

C Coarse

VC Very coarse

\section{CARBONATES:}

M Mudstone

W Wackestone

P/G Packstone/Grainstone

F/R Floatstone/Rudstone

B Boundstone

- SURFACES -

Abrupt lithological change, a priori continuous

(6) With ammonites above

m Erosive surface

\section{- MAIN ELEMENTS -}

BIOCLASTIC ELEMENTS:

\begin{tabular}{|c|c|c|c|}
\hline$\Longleftrightarrow$ & Siliceous sponges & 0 & Ostracods \\
\hline$\bigoplus$ & Corals (isolated, fragments) & (2) & Brachiopods \\
\hline 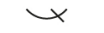 & Unidentified bioclasts & $\Leftrightarrow$ & Bivalves \\
\hline & Large shells & & Echinoids \\
\hline$\sim$ & Platy corals & 8 & Gastropods \\
\hline as & Tubular sponges & $\infty$ & Serpulids \\
\hline \multicolumn{2}{|c|}{ NON-BIOCLASTIC ELEMENTS: } & \multicolumn{2}{|c|}{ POROSITY: } \\
\hline \multirow{2}{*}{$\approx$} & Oncoids & 3 & Vugs \\
\hline & Cherts & & \\
\hline & Dolomite crystals & & \\
\hline \multirow[t]{2}{*}{ 䍐 } & Plants fragments & & \\
\hline & \multicolumn{3}{|c|}{ - SEDIMENTARY STRUCTURES - } \\
\hline & Ripples & & Flaser bedding \\
\hline$\widehat{\Lambda}$ & Wave ripples & & De-watering structures \\
\hline & Hummocky cross-stratification & V & Bioturbation \\
\hline \multirow[t]{2}{*}{$\sim$} & Flute casts & $\sim$ & Hardground \\
\hline & & $\Longrightarrow$ & Stromatactis, binding fab \\
\hline
\end{tabular}

\section{- STRATIGRAPHY STRUCTURES -}

Plan-concave, channel shape

(1) Slump

Wavy bedding

0 Olistolith

Mud mound

Fig. 7B 


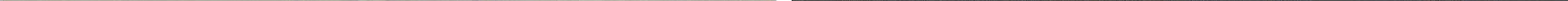


A
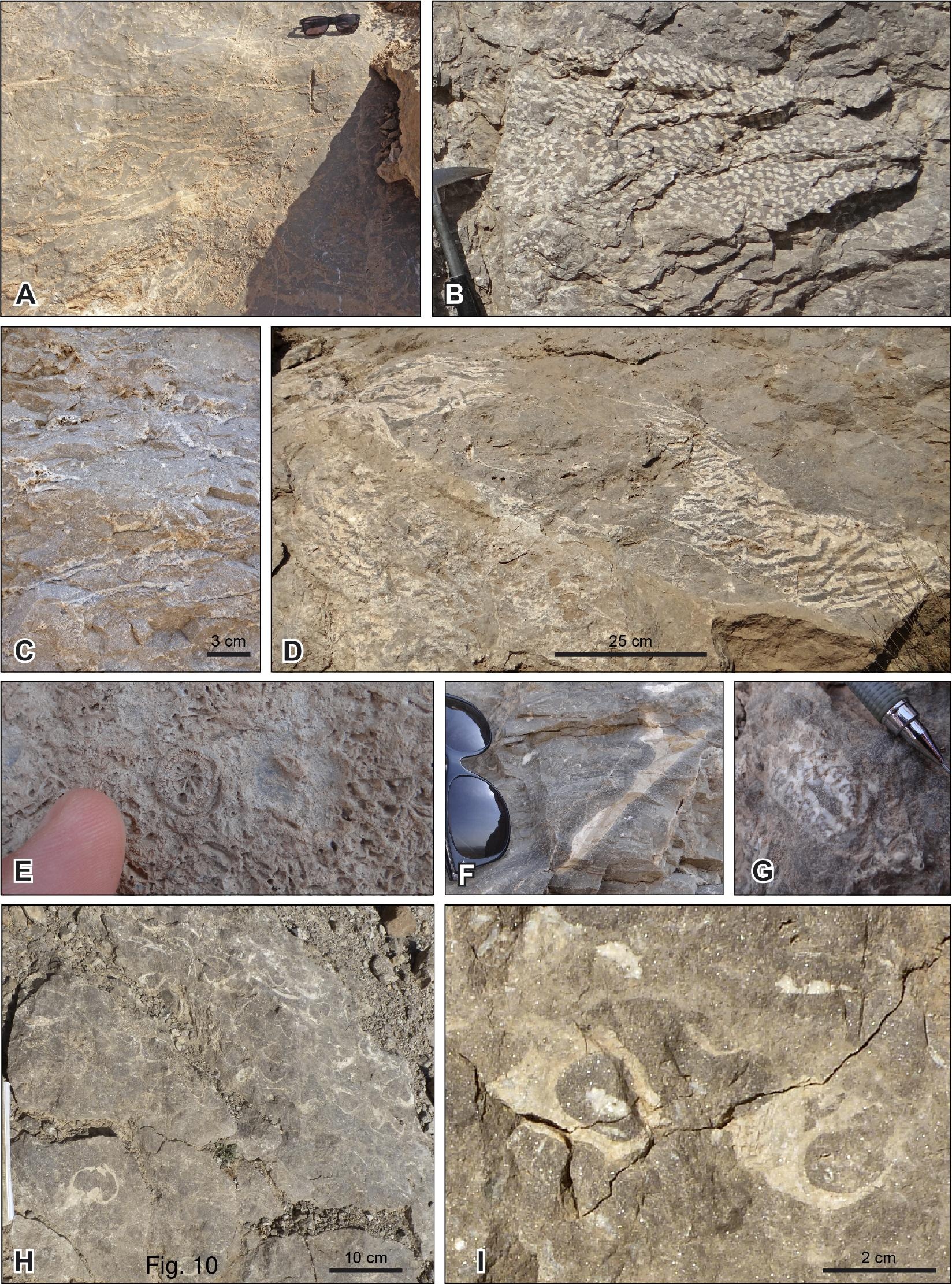


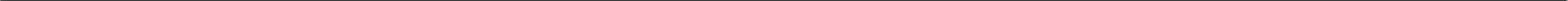




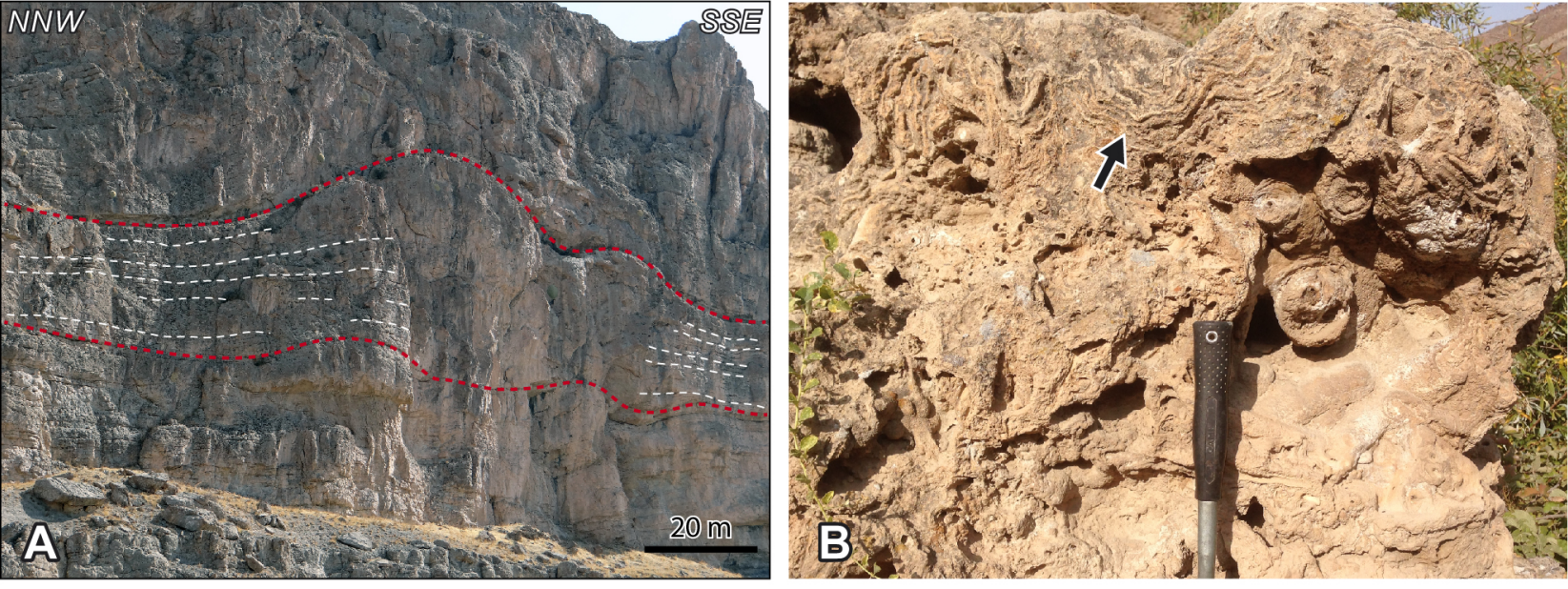

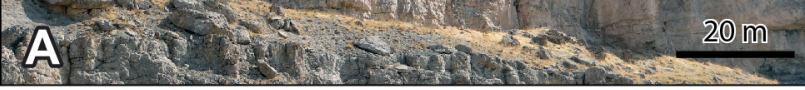
B. $)^{2}=$

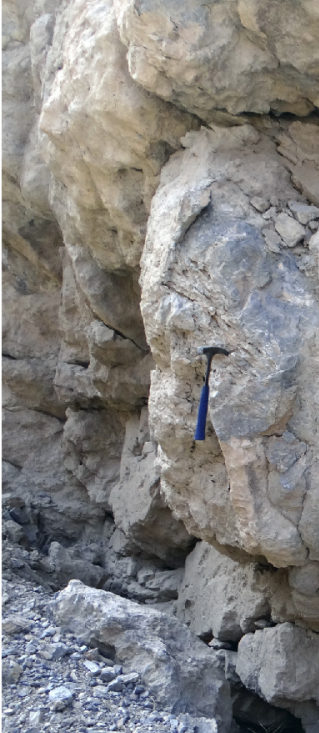

C.
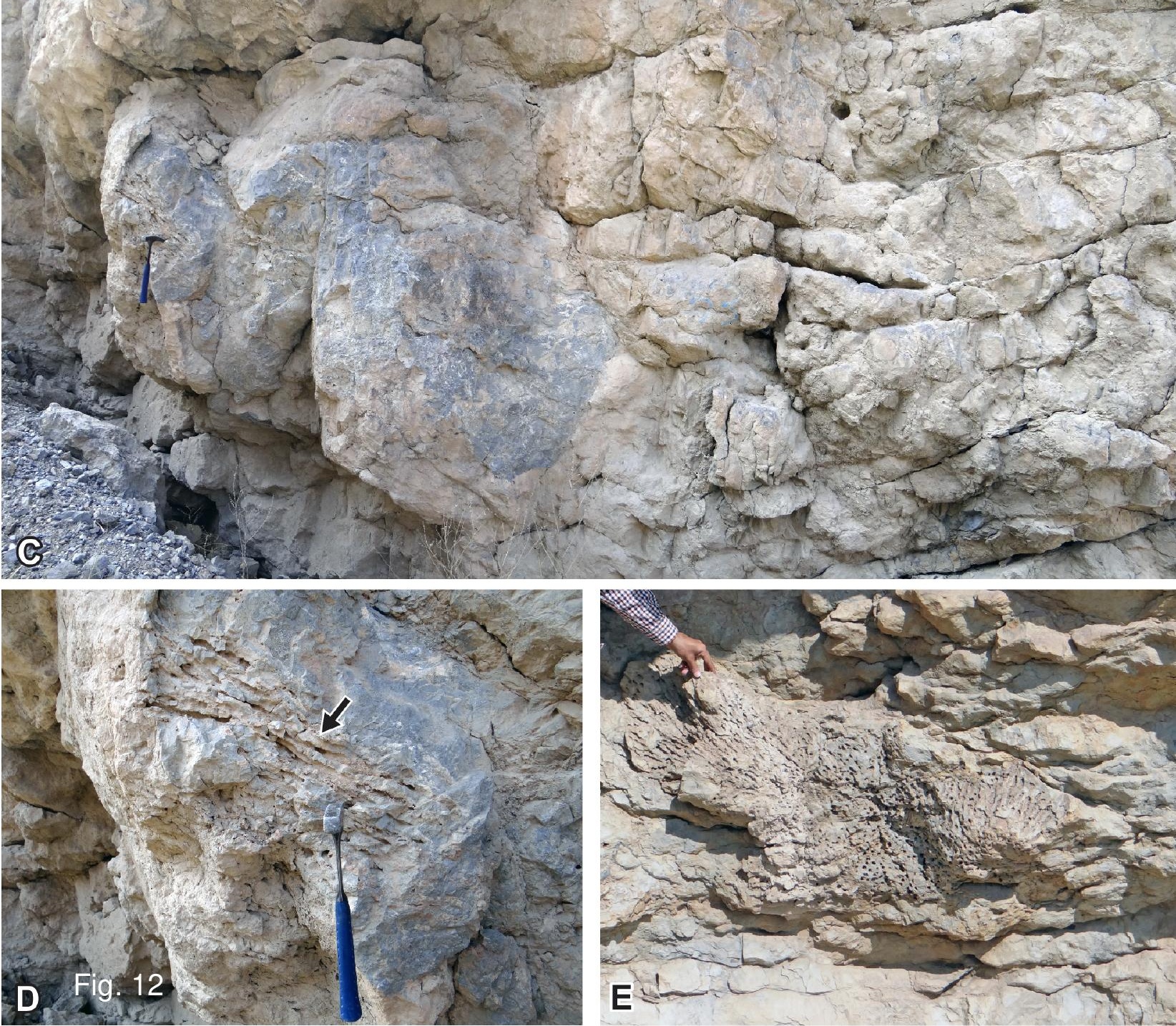
wsw $z-2$

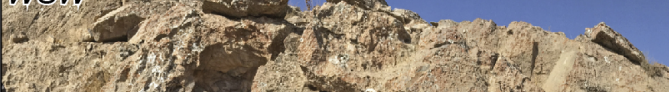

1)

$\left.12-x^{2}-1\right)$

(2)

A.

-

\section{WSW}

$\frac{3}{-1}$

$\left.n^{2}\right)^{2}$

1.

I Si.

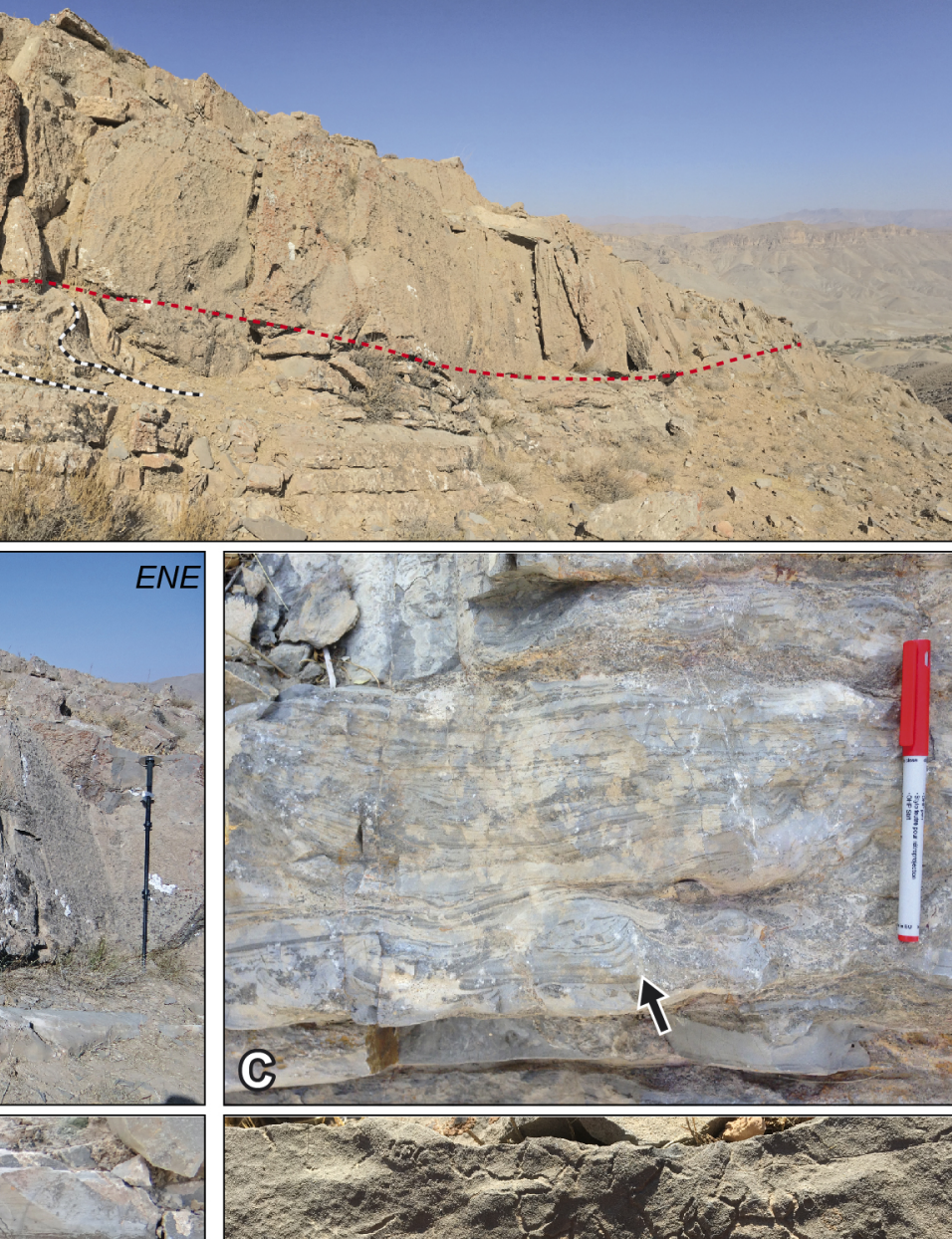

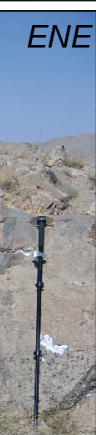

46.

3

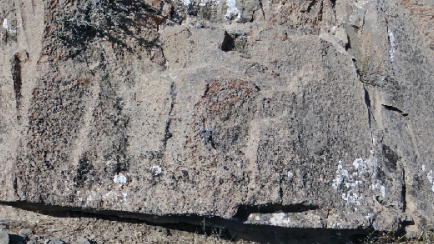

E<smiles>[AlH2]</smiles>

$+-\rightarrow+x^{2}$

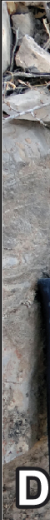

4. 2.42 .4

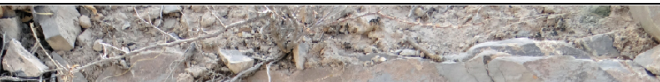
(1)

1

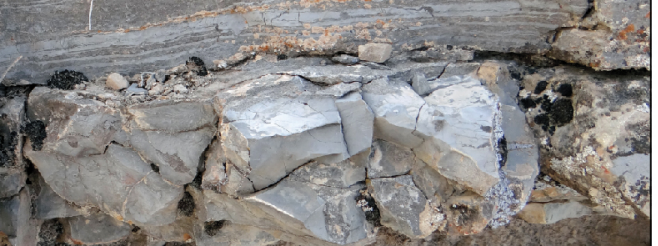

$\int_{2}^{1}=\frac{1}{2}$

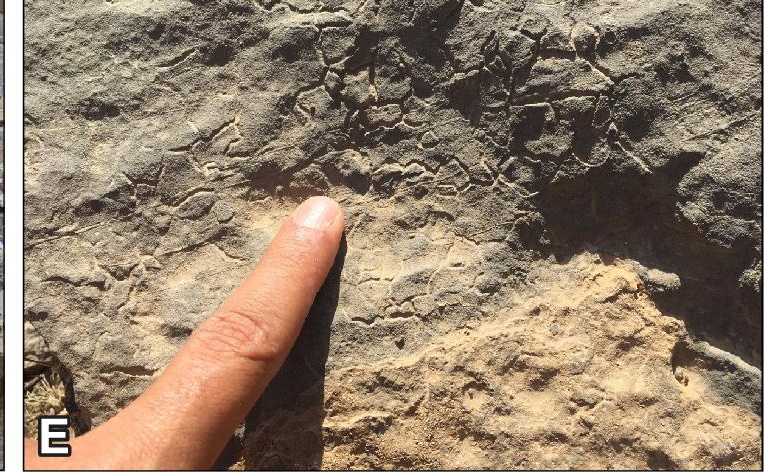




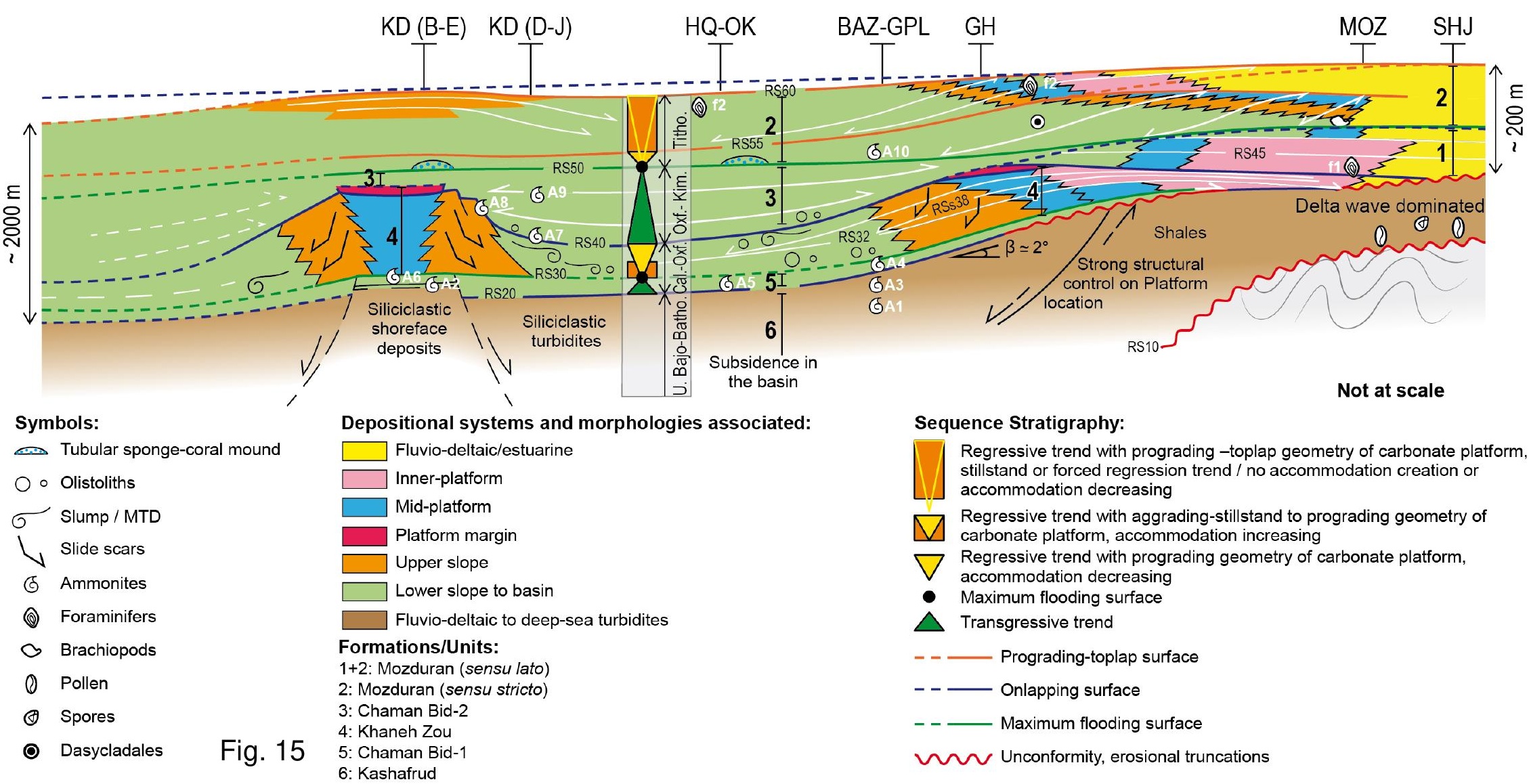

\section{Symbols:}

$\approx$ Tubular sponge-coral mound

$\bigcirc \circ$ Olistoliths

$\sigma$

(1) Foraminifers

O Brachiopods

() Pollen

O Dasycladales
Fig. 15
Depositional systems and morphologies associated:

2. Mozduran (sensu lato)

6: Kashafrud 

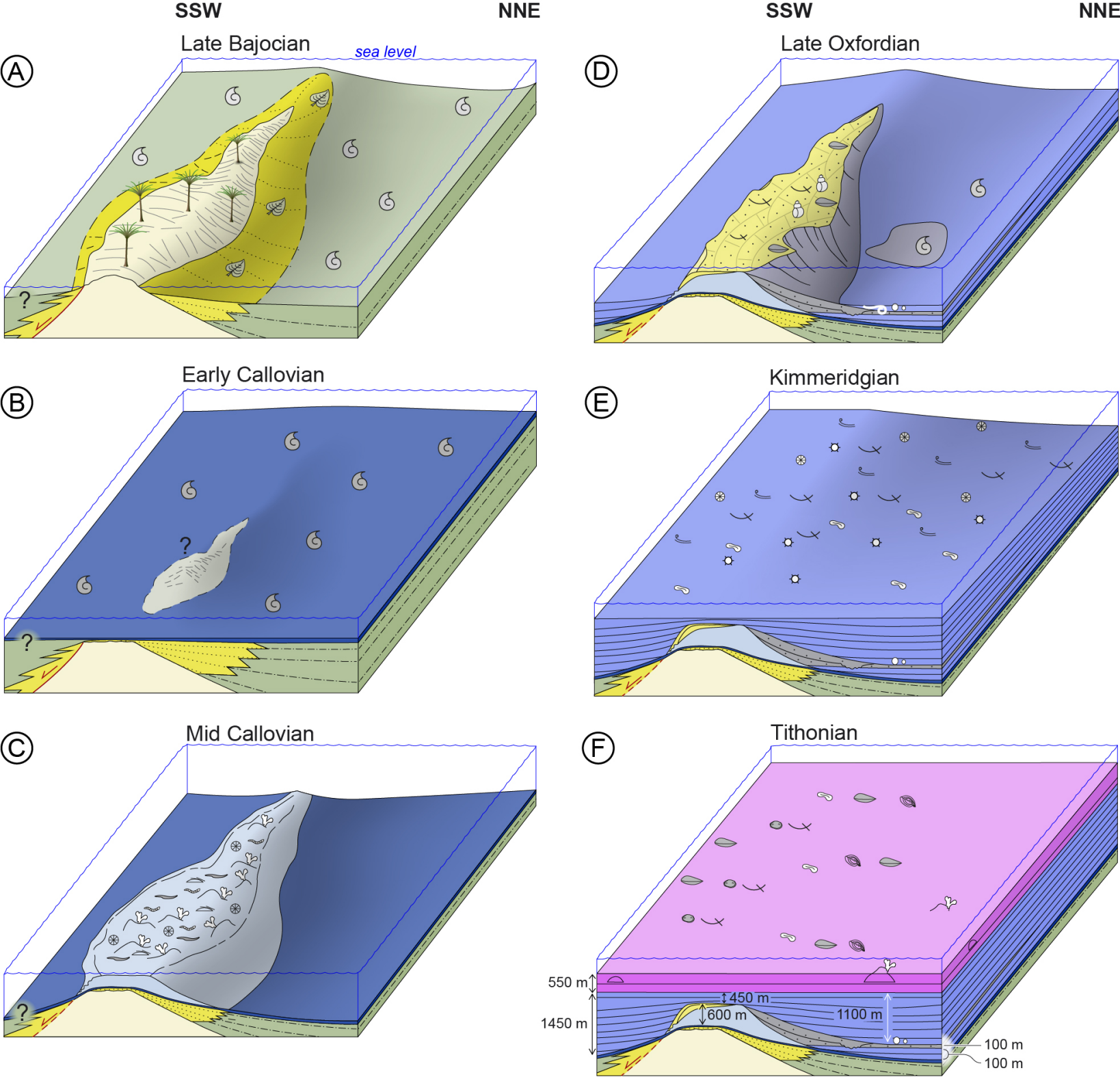

Palaeohigh Kashafrud Fm. $1 \ldots 2$

1: Shoreface sand

2: Marine shaly sand

Fig. 16
Khaneh Zou Fm. 475

3: Mud-dominated platform carbonates

4: Off-platform grainstones

5: Calciturbidites
Chaman Bid Fm. $6 \hat{6}$

6: Basal mudstone/wackestone (Chaman Bid-1)

7: Hemipelagic mudstone and slope deposits (Chaman Bid-2)
Mozduran Fm.

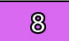

8: Ramp carbonates with tubular sponges and coral mounds 


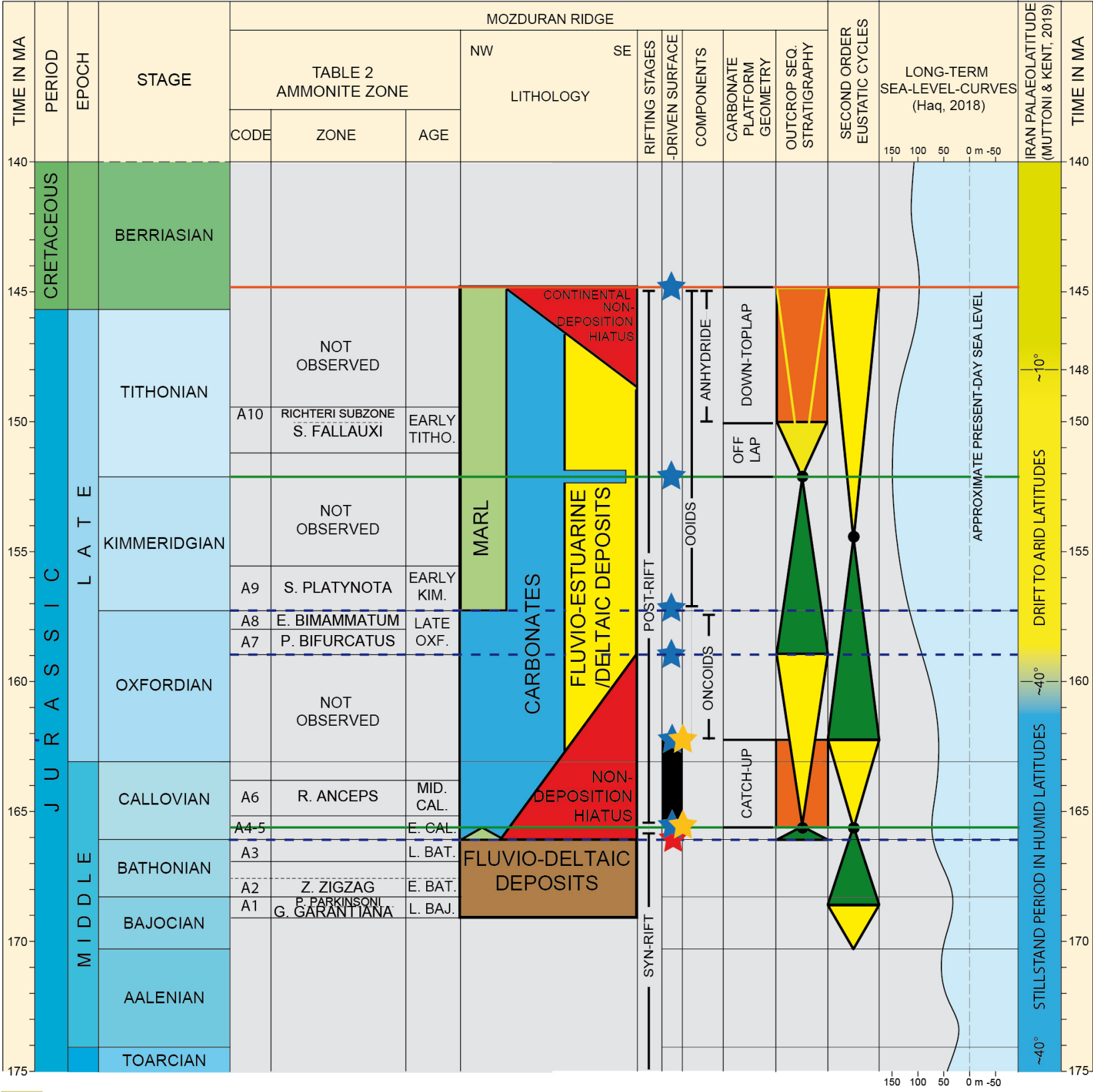

Regressive trend with prograding-toplap geometry of carbonate platform, stillstand or forced regressive trend / no accommodation creation or accommodation decreasing

Regressive trend with aggrading-stillstand to prograding geometry of carbonate platform, accommodation increasing Regressive trend with prograding geometry of carbonate platform, accommodation decreasing

Maximum flooding surface

Transgressive trend

Prograding-toplap pattern surface

Maximum flooding surface
Structural-enhanced surface

Subsidence masking eustatic trend 


\section{Table 1 Main lithofacies of different types of the Callovian-Tithonian carbonate system in Eastern Kopet Dagh.}

\begin{tabular}{|c|c|c|c|c|}
\hline $\begin{array}{l}\text { Lithofacies } \\
\text { code }\end{array}$ & Lithology/Texture & Bioclast content & Sedimentary and diagenetic features & Depositional environment \\
\hline F1a & Sandstone & Low; some molluscs & Carbonate cement, with cherts. & $\begin{array}{l}\text { Tide-dominated fluvio-deltaic/ } \\
\text { estuarine }\end{array}$ \\
\hline F1b & Sandstone & Low & $\begin{array}{l}\text { Ripple marks, low-angle lamination, large-scale trough and } \\
\text { planar cross-bedding (herringbone). }\end{array}$ & $\begin{array}{l}\text { Tide-dominated fluvio-deltaic/ } \\
\text { estuarine }\end{array}$ \\
\hline F2 & Siltstone and Claystone & Low & Burrows. & Tidal flat \\
\hline F3 & Marl/Mudstone & Ammonites, oysters, sponges & $\begin{array}{l}\text { Monotonous alternating hemipelagic succession, bioturbated, } \\
\text { compacted, occasionally with cherts. }\end{array}$ & Lower slope to basin \\
\hline F4 & Grainstone-Rudstone & Reworked oncoids, corals, Trichites, molluscs & $\begin{array}{l}\text { Turbidites with erosional base, massive, graded, coarse- } \\
\text { grained at base, fine-grained at top. }\end{array}$ & Upper slope to basin \\
\hline F5 & Cherty limestone (wackestone/packstone) & Low; mainly molluscs and brachiopods & $\begin{array}{l}\text { Occasionally with synsedimentary deformation: various } \\
\text { slump features. }\end{array}$ & Lower slope to basin \\
\hline F6 & Oncoid packstone & Oncoids, Trichites, brachiopods, molluses, sponges & $\begin{array}{l}\text { Massive, muddy, bioclasts randomly distributed, } \\
\text { Occasionally with decreasing bioclasts size. }\end{array}$ & Inner-platform to lower slope \\
\hline F7 & Floatstone/Rudstone & Sponges, platy corals, stromatactis-like objects, molluscs, tubular sponges & $\begin{array}{l}\text { Matrix- or grain-supported fabric. Skeletal elements partly } \\
\text { floating in early diagenetically lithified mudstone matrix. }\end{array}$ & Mid-platform to upper slope \\
\hline F8 & Platestone-Mixstone & Platy corals, serpulids, stromatactis-like objects & $\begin{array}{l}\text { Aggregates of colonial organisms in growth position, } \\
\text { mudstone matrix. }\end{array}$ & Mid-platform to upper slope \\
\hline F9 & Wackestone & Coral bouquets, ostracods, sponges & Sedimentary features lacking. Microbial carbonate mound. & Inner-platform \\
\hline F10 & Grainstone & $\begin{array}{l}\text { Undifferentiated bioclasts i.e. echinoids, molluscs (fragments of diceratids), } \\
\text { foraminifers }\end{array}$ & Foresets beds (a few meters thick), occasionally with cherts. & Platform margin \\
\hline
\end{tabular}


Table 2 Selected biostratigraphic data (Middle-Late Jurassic) located in Fig. 15 and compiled from this study and previous publications across the Kopet Dagh Basin. Suggested age of the formations: Kashafrud: Late Bajocian-Bathonian; Chaman Bid-1: Early Callovian; Khaneh Zou: Middle Callovian-late Oxfordian; Chaman Bid-2: Late Oxfordian-Kimmeridgian (the base of Chaman Bid-2 is a diachronous surface depending on the onlapping onto the Khaneh Zou); Mozduran: Tithonian.

in

Type oi Name/Zone

Age

Locality/Region Formation/ Reference

Unit

A1 Garantiana and parkinsoni zones

Late Bajocian

Gas Pipeline

Kashafrud

Hosseiniyoon et al. (2017)

A2 Ebrayiceras sp. (zigzag Zone)

Early Bathonian

Kardeh (E)

Kashafrud

This study

Prohecticoceras haugi

A3 Cadomites claramontanus

Procerites (Siemiradzkia) sp.

Late Bathonian

Gas Pipeline

Kashafrud

Taheri et al. (2009)

Homoeoplanulites sp.

\section{Choffatia sp.}

A4 Macrocephalites sp.

Ptychophylloceras sp.

A5 ?Macrocephalites sp.

Anceps Zone:

Hecticoceras cf. lunuloides

A6 Reineckeia anceps

Phylloceras sp.

Calliphylloceras sp.

Sowerbyceras sp.

\section{Callovian}

Early Callovian

Bathonian-Oxfordian

Callovian

Callovian

Kardeh (E)

Chaman Bid-1 This study
A7 Dichotomoceras sp. (bifurcatus Zone)
Late Oxfordian
Kardeh (J)
Chaman Bid-2 This study

Euaspidoceras sp.

Late Callovian-late Kimmeridgian Kardeh (D)

A8

Subdiscosphinctes sp. (bimammatum Zone) Late Oxfordian

$\operatorname{Kardeh}(\mathrm{G})$

Grainstones of This study
Khaneh Zou

A9

Perisphinctidae

Kimmeridgian

Early Kimmeridgian

Kardeh (J)

Chaman Bid-2 This study

A10 Richterella richteri (fallauxi Zone)

Early Tithonian

Bazangan

Chaman Bid

Mozduran

Hosseiniyoon et al. (2017)

(Western Kopet Dagh)

Chaman Bid Majidifard et al. (2017)

Moeschia sp.

B Uralella sp.

Torquirhynchia sp.

Early Tithonian

Mozduran

Mozduran

Adabi and Ager (1997)

f1 Alveoseptajaccardi

f2 Anchispirocyclina lusitanica

Pollen

$\mathrm{Sp}$

Petrascula bugesiaca

Triploporella sp.
Oxfordian-Kimmeridgian

Tithonian-early Berriasian

Early-Mid Jurassic

Late Bajocian-early Bathonian

Tithonian

\section{Mozduran}

Abgarm

Hammam Qaleh

Aghdarband area

Aghdarband area
Mozduran (sensu lato)

Mozduran

Shemshak?

Kashafrud

Kashafrud

Mozduran

Schlagintweit et al. (2019)
Kadivar et al. (2017)

This study

modified after Jamali (2011)

Madani (1977)

Sajjadi and Hadad Tavakol (2008)

-


